\title{
Spermatogonial stem cells in higher primates: are there differences from those in rodents?
}

\author{
Brian P Hermann ${ }^{1,3,5}$, Meena Sukhwani ${ }^{5}$, Marc C Hansel ${ }^{4}$ and Kyle E Orwig 1,2,3,5 \\ ${ }^{1}$ Department of Obstetrics, Gynecology and Reproductive Sciences, ${ }^{2}$ Department of Microbiology and Molecular \\ Genetics, ${ }^{3}$ Center for Research in Reproductive Physiology and ${ }^{4}$ Interdisciplinary Biomedical Graduate Program, \\ University of Pittsburgh School of Medicine, Pittsburgh, Pennsylvania 15260, USA and ${ }^{5}$ Magee-Womens Research \\ Institute, University of Pittsburgh School of Medicine, 204 Craft Avenue, Pittsburgh, Pennsylvania 15213, USA
}

Correspondence should be addressed to K E Orwig at Magee-Womens Research Institute, University of Pittsburgh School of Medicine; Email: orwigke@upmc.edu

\begin{abstract}
Spermatogonial stem cells (SSCs) maintain spermatogenesis throughout the reproductive life of mammals. While $A_{\text {single }}$ spermatogonia comprise the rodent SSC pool, the identity of the stem cell pool in the primate spermatogenic lineage is not well established.

The prevailing model is that primate spermatogenesis arises from $A_{\text {dark }}$ and $A_{\text {pale }}$ spermatogonia, which are considered to represent reserve and active stem cells respectively. However, there is limited information about how the $A_{\text {dark }}$ and $A_{\text {pale }}$ descriptions of nuclear morphology correlate with the clonal $\left(A_{\text {single }}, A_{\text {paired, }}\right.$ and $\left.A_{\text {aligned }}\right)$, molecular (e.g. GFR 1 (GFRA1) and PLZF), and functional (SSC transplantation) descriptions of rodent SSCs. Thus, there is a need to investigate primate SSCs using criteria, tools, and approaches that have been used to investigate rodent SSCs over the past two decades. SSCs have potential clinical application for treating some cases of male infertility, providing impetus for characterizing and learning to manipulate these adult tissue stem cells in primates (nonhuman and human). This review recounts the development of a xenotransplant assay for functional identification of primate SSCs and progress dissecting the molecular and clonal characteristics of the primate spermatogenic lineage. These observations highlight the similarities and potential differences between rodents and primates regarding the SSC pool and the kinetics of spermatogonial self-renewal and clonal expansion. With new tools and reagents for studying primate spermatogonia, the field is poised to develop and test new hypotheses about the biology and regenerative capacity of primate SSCs.

Reproduction (2010) 139 479-493
\end{abstract}

Progress characterizing SSCs and development of the spermatogenic lineage in rodents may provide insights about the identity and characteristics of nonhuman primate and human SSCs. Here, we provide a review of tools and strategies used to characterize rodent SSCs, and summarize classical and contemporary approaches for studying primate SSCs. We will conclude with comments on the evolutionary conservation of SSC phenotype and function from rodents to primates and future studies that may help to elucidate the mode of stem cell renewal and differentiation in primates.

\section{Spermatogonial stem cells in rodents}

Spermatogonial stem cells (SSCs) are undifferentiated germ cells that balance self-renewing and differentiating divisions to maintain spermatogenesis throughout adult life. This is a productive stem cell system that produces millions of sperms each day while also maintaining rigorous quality control to safeguard germline integrity. Investigating the biological properties of SSCs that achieve this delicate balance in vivo will expand the understanding of stem cell/niche interactions in a variety of adult tissues and may also have implications for treating male infertility. Despite their critical importance to spermatogenesis and male fertility, the cellular and molecular characteristics of SSCs remain largely undefined. Experimental determination of the basic characteristics of SSCs requires a standardized biological assay that detects the capacity to initiate and maintain spermatogenesis. A SSC transplantation technique, developed for mice in 1994, measures this endpoint, and, thus, functionally evaluates stem cell activity in any mouse testis cell preparation (Brinster \& Avarbock 1994, Brinster \& Zimmermann 1994). Briefly, germ cells are isolated from the testes of donor animals and transplanted into the seminiferous tubules of infertile recipients where they produce colonies of spermatogenesis and functional sperm. Only a stem cell can produce 
and maintain a colony of spermatogenesis, and each colony in recipient testes arises from the clonogenic proliferation and differentiation of a single SSC (Dobrinski et al. 1999b, Nagano et al. 1999, Zhang et al. 2003, Kanatsu-Shinohara et al. 2006). Application of this technique in rodents revealed that SSCs from donors of all ages (newborn to adult) are competent to produce complete spermatogenesis in the testes of infertile males (Brinster \& Avarbock 1994, Ogawa et al. 2000, Ohta et al. 2000, Nagano et al. 2001 a, Shinohara et al. 2001, Brinster et al. 2003, Ryu et al. 2003). In addition to rodents, SSC transplantation has successfully generated complete spermatogenesis in other higher species, including goats (Honaramooz et al. 2003), pigs (Mikkola et al. 2006), and dogs (Kim et al. 2008). These results may have future implications for treating some cases of human male infertility (reviewed by Orwig \& Schlatt (2005), Brinster (2007) and Schlatt et al. (2009)). In addition, fluorescence-activated cell sorting (FACS) combined with SSC transplantation has also enabled systematic characterization of mouse SSCs as a subpopulation of mouse testis cells defined by the phenotype $\alpha 6$-INTEGRIN ${ }^{+}, \beta 1$-INTEGRIN ${ }^{+}$, THY $^{+}{ }^{\text {, }}$ $\mathrm{CD}^{+}{ }^{+}$Hoechst side population ${ }^{+}$, Rho123 low $^{\text {, }}$ av-INTEGRIN ${ }^{-}, \mathrm{KIT}^{-}\left(\mathrm{CKIT}^{-}\right)$, major histocompatibility complex class I (MHC-I) ${ }^{-}$, and CD45 ${ }^{-}$(Shinohara et al. 1999, 2000, Kubota et al. 2003, Falciatori et al. 2004, Kanatsu-Shinohara et al. 2004, Lassalle et al. 2004, Fujita et al. 2005, Lo et al. 2005). Rodent SSCs can also be identified in whole mount preparations of testicular seminiferous tubules (initially described by Clermont \& Bustos-Obregon (1968)) as isolated $\mathrm{A}_{\text {single }}$ spermatogonia and probably some $A_{\text {paired }}$ spermatogonia. These $\mathrm{A}_{\text {single }}$ SSCs can be distinguished in whole mount from committed progenitor spermatogonia (some $A_{\text {paired }}$ and $A_{\text {aligned }}$ chains of 4-16 cells) on the basement membrane of seminiferous tubules because committed cells exist as clonal chains connected by intercellular cytoplasmic bridges. Here, we define progenitors as undifferentiated spermatogonia that are committed to differentiate and can undergo a finite number of self-renewing divisions. Although no SSC-specific marker has been identified, whole mount analyses indicate that GFR $\alpha 1$ (GFRA1), PLZF (ZBTB16), CDH1, NGN3 (NEUROG3) and POU5F1 (OCT3/4) are expressed by undifferentiated stem and progenitor spermatogonia, including $A_{\text {single, }}$ $A_{\text {paired, }}$ and $A_{\text {aligned 4-16 }}$ (Buaas et al. 2004, Yoshida et al. 2004, Greenbaum et al. 2006, Nakagawa et al. 2007, Tokuda et al. 2007, Schlesser et al. 2008). In contrast, the KIT receptor tyrosine kinase is absent from $A_{\text {single, }} A_{\text {paired, }}$ and most $A_{\text {aligned }}$ spermatogonia, but initiates expression in larger $A_{\text {aligned }}$ Clones ( 8 and 16 cells) and continues in differentiating types A1-4, intermediate, and B spermatogonia (Manova et al. 1990, Sorrentino et al. 1991, Yoshinaga etal. 1991, Tajima et al. 1994, Dym etal. 1995, Schrans-Stassen et al. 1999). Initiation of KIT expression marks the transition from undifferentiated $A_{\text {aligned }}$ spermatogonia to differentiating A1 spermatogonia (Schrans-Stassen et al. 1999). Thus, based on whole mount analyses and molecular phenotyping in rodents, it is possible to distinguish stem/progenitor spermatogonia $\left(\mathrm{A}_{\text {single, }} \mathrm{A}_{\text {paired, }}\right.$ and $\mathrm{A}_{\text {aligned; }}$ GFRA1 ${ }^{+}, \mathrm{PLZF}^{+}$, $\mathrm{NGN}^{+/-}$, and $\left.\mathrm{KIT}^{-}\right)$and differentiating spermatogonia (A1-4, intermediate, and B; GFRA ${ }^{-}$, $\mathrm{PLZF}^{-}$, $\mathrm{NGN3}^{+/-}$, and $\mathrm{KIT}^{+}$).

Mammalian spermatogenesis occurs in a synchronized, cyclic pattern where the cellular associations of differentiating germ cells and Sertoli cells are maintained in a progressive and repeated fashion (de Rooij \& Russell 2000). Using this information, the seminiferous epithelium can be categorized into numerous discrete 'stages' based upon the cellular complement observed in a given segment of seminiferous tubule. Thorough evaluation of these cellular associations has identified 12 discrete stages of the seminiferous epithelium in mice and 14 stages in rats (Table 1; Leblond \& Clermont 1952, Oakberg 1956).

Morphometric whole mount studies have demonstrated that the numbers of $\mathrm{A}_{\text {single }}$ in mice, rats, and Chinese hamsters remain relatively constant throughout the spermatogenic cycle, apparently due to the balanced renewal of $A_{\text {single }}$ and formation of $A_{\text {paired }}$ (Fig. 1A; Huckins 1971, Oakberg 1971, de Rooij 1973, Lok et al. 1982, Tegelenbosch \& de Rooij 1993). Likewise, numbers of $A_{\text {paired }}$ are relatively constant across the seminiferous cycle (Fig. 1A). In contrast, the density of $\mathrm{A}_{\text {aligned }}$ is cyclic and is lowest at stages IX-XI, after large $\mathrm{A}_{\mathrm{aligned}}$ clones produce differentiating A1 spermatogonia, and highest at stage $\mathrm{VI}$ of the subsequent cycle, as $A_{\text {aligned }}$ clones become larger prior to recruitment to A1 (Fig. 1A). Morphometric quantification of total undifferentiated spermatogonial numbers per testis indicates that there are roughly $35000 \mathrm{~A}_{\text {single }}$ per testis, representing roughly $0.03 \%$ of all testicular germ cells $(1.3 \%$ of spermatogonia or $10.6 \%$ of undifferentiated spermatogonia; Tegelenbosch \& de Rooij 1993).

\section{Identity and arrangement of undifferentiated spermatogonia in primates}

Clermont \& Leblond (1959) initially described two morphologically distinct types of undifferentiated spermatogonia in the testes of rhesus macaques, and designated these cells $A_{1}$ and $A_{2}$ (later renamed $A_{\text {dark }}$ and $A_{\text {pale }}$ respectively; Clermont \& Antar 1973). Both cell types are present on the basement membrane of primate seminiferous tubules, but differ based on nuclear architecture and staining intensity with hematoxylin. Clermont proposed that $A_{\text {dark }}$ were SSCs, which undergo self-renewing divisions to maintain the stem cell pool and give rise to $A_{\text {pale }}$ that subsequently generate differentiating type-B spermatogonia (Clermont \& Leblond 1959). 
Table 1 Stages of the cycle of the seminiferous epithelium in rodents and primates.

\begin{tabular}{|c|c|c|c|c|c|}
\hline \multirow[b]{2}{*}{ Species } & \multirow[b]{2}{*}{ Stages $(\#)$} & \multicolumn{2}{|c|}{ Duration (days) } & \multirow{2}{*}{$\begin{array}{l}\text { Stages per cross } \\
\text { section }^{\mathrm{a}}\end{array}$} & \multirow[b]{2}{*}{ References } \\
\hline & & One cycle & Spermatogenesis & & \\
\hline Homo sapiens & 6 & 16 & 64 & $2-4$ & $\begin{array}{l}\text { Clermont (1963, 1966a, 1966b), Heller \& } \\
\text { Clermont (1963) and Amann (2008) }\end{array}$ \\
\hline Pan troglodytes (chimpanzee) & 6 & 14 & 62.5 & $2-4(1-5)$ & $\begin{array}{l}\text { Smithwick \& Young (1996) and Smithwick } \\
\text { et al. (1996) }\end{array}$ \\
\hline Papio anubis (olive baboon) & 12 & 11 & 42 & $1-3$ & $\begin{array}{l}\text { Chowdhury \& Marshall (1980) and } \\
\text { Chowdhury \& Steinberger (1976) }\end{array}$ \\
\hline $\begin{array}{l}\text { Macaca arctoides } \\
\text { (stump-tailed macaque) }\end{array}$ & 12 & 11.6 & 46.4 & 1 & $\begin{array}{l}\text { Clermont (1972) and Clermont \& Antar } \\
\text { (1973) }\end{array}$ \\
\hline $\begin{array}{l}\text { Macaca fascicularis } \\
\text { (cynomolgus monkey) }\end{array}$ & 12 & 10.5 & 42 & 1 to several & $\begin{array}{l}\text { Dietrich et al. (1986) and Fouquet \& } \\
\text { Dadoune (1986) }\end{array}$ \\
\hline $\begin{array}{l}\text { Macaca mulata } \\
\text { (rhesus macaque) }\end{array}$ & 12 & 10.5 & 42 & 1 & $\begin{array}{l}\text { Clermont \& Leblond (1959), } \\
\text { de Rooij et al. (1986) and Rosiepen et al. } \\
\text { (1997) }\end{array}$ \\
\hline $\begin{array}{l}\text { Callithrix jacchus } \\
\text { (common marmoset) }\end{array}$ & 9 & 10 & 37 & $1-5$ & $\begin{array}{l}\text { Holt \& Moore (1984) and Millar et al. } \\
\quad(2000)\end{array}$ \\
\hline Mus musculus & 12 & 8.62 & 34.5 & 1 & $\begin{array}{l}\text { Oakberg (1956, 1971), Clermont \& Trott } \\
\text { (1969) and Kluin et al. (1982) }\end{array}$ \\
\hline Rattus norvenicus & 14 & 13 & 51.6 & 1 & $\begin{array}{l}\text { Leblond \& Clermont (1952), Clermont \& } \\
\quad \text { Perey (1957) and Huckins (1971) }\end{array}$ \\
\hline $\begin{array}{l}\text { Cricetulus griseus (Chinese } \\
\text { hamster) }\end{array}$ & 12 & 17 & 68 & 1 & $\begin{array}{l}\text { Clermont \& Trott (1969) and } \\
\text { Oud \& de Rooij (1977) }\end{array}$ \\
\hline $\begin{array}{l}\text { Mesocricetus brandti } \\
\text { (Turkish hamster) }\end{array}$ & 8 & 8 & 32 & 1 & Myoga et al. (1991) \\
\hline $\begin{array}{l}\text { Mesocricetus auratus } \\
\text { (Golden hamser) }\end{array}$ & 13 & 8.74 & 35 & 1 & $\begin{array}{l}\text { Leblond \& Clermont (1952) and Miething } \\
\text { (1998) }\end{array}$ \\
\hline
\end{tabular}

${ }^{a}$ Evidence of discrete stages of the seminiferous epithelium in individual cross sections of seminiferous tubules.

Ten years after the initial description of $A_{\text {dark }}$ and $A_{\text {pale }}$ spermatogonia, Clermont (1969) revised his linear ' $A_{\text {dark }}$ stem cell- $\mathrm{A}_{\text {pale }}$ progenitor model' based on the observations in the vervet monkey (Cercopithecus aethiops) that $A_{\text {dark }}$ failed to label with ${ }^{3} \mathrm{H}$-thymidine. Thus, since $A_{\text {dark }}$ did not appear to self-renew under steady-state conditions, Clermont (1969) proposed that $A_{\text {dark }}$ and $A_{\text {pale }}$ represent reserve and active stem cells respectively. In this 'reserve stem cell' model, spermatogenesis is maintained by the 'active' pool of $A_{\text {pale }}$ SSCs under normal circumstances. A similar model has been proposed for human spermatogenesis, where both $A_{\text {dark }}$ and $A_{\text {pale }}$ spermatogonia are present, and active $A_{\text {pale }}$ proliferation maintains spermatogenesis by balancing the production of differentiating $B$ spermatogonia and by renewing the $A_{\text {pale }}$ pool ((Clermont 1966a, 1966b), reviewed in Amann (2008) and Dym et al. (2009)). Alternatively, others have proposed that the low mitotic index of $A_{\text {dark }}$ is specifically indicative of a 'true SSC' phenotype, while the regular divisions of nearly all $A_{\text {pale }}$ demonstrate that these cells are 'renewing progenitors' that amplify spermatogonial output to B1 (reviewed by Ehmcke \& Schlatt (2006) and Ehmcke et al. (2006)).

Similar to rodents, 12 distinct stages of the seminiferous epithelium have been described for stump-tailed macaques, cynomolgus monkeys, rhesus macaques, and baboons, while marmosets and chimpanzees stages are reported to have nine and six stages respectively
(Table 1; Clermont \& Leblond 1959, Clermont \& Antar 1973, Chowdhury \& Steinberger 1976, Holt \& Moore 1984, Fouquet \& Dadoune 1986, de Rooij et al. 1986, Smithwick \& Young 1996). Similar to chimpanzees, morphological examination of human spermatogenesis identified only six stages based on discrete cellular associations (Table 1; Clermont 1963, 1966a, Heller \& Clermont 1963; reviewed by Amann (2008)). The topological arrangement of stages in human seminiferous tubules is described as spiral or patchy where one cross section may contain germ cells in two to four different stages (Amann 2008). This arrangement is different from the 'linear' arrangement described for rodents where a given seminiferous tubule cross section contains only one stage (Table 1 ). Different nonhuman primate species exhibit varying degrees of 'linear' or 'patchy' stage topography (Table 1).

As for rodents, numbers and distribution of undifferentiated spermatogonia along the seminiferous epithelium have been described for primates. Morphometric studies indicate that the adult rhesus testis contains roughly equal numbers of $A_{\text {dark }}$ and $A_{\text {pale }}$ (Marshall \& Plant 1996). In the rhesus testis, $A_{\text {dark }}$ are equally distributed along the length of the seminiferous tubule epithelium and do not fluctuate significantly between stages (Fig. 1B, red line; Clermont \& Leblond 1959, Fouquet \& Dadoune 1986). Cells with an indeterminate 'transition' phenotype also do not vary 

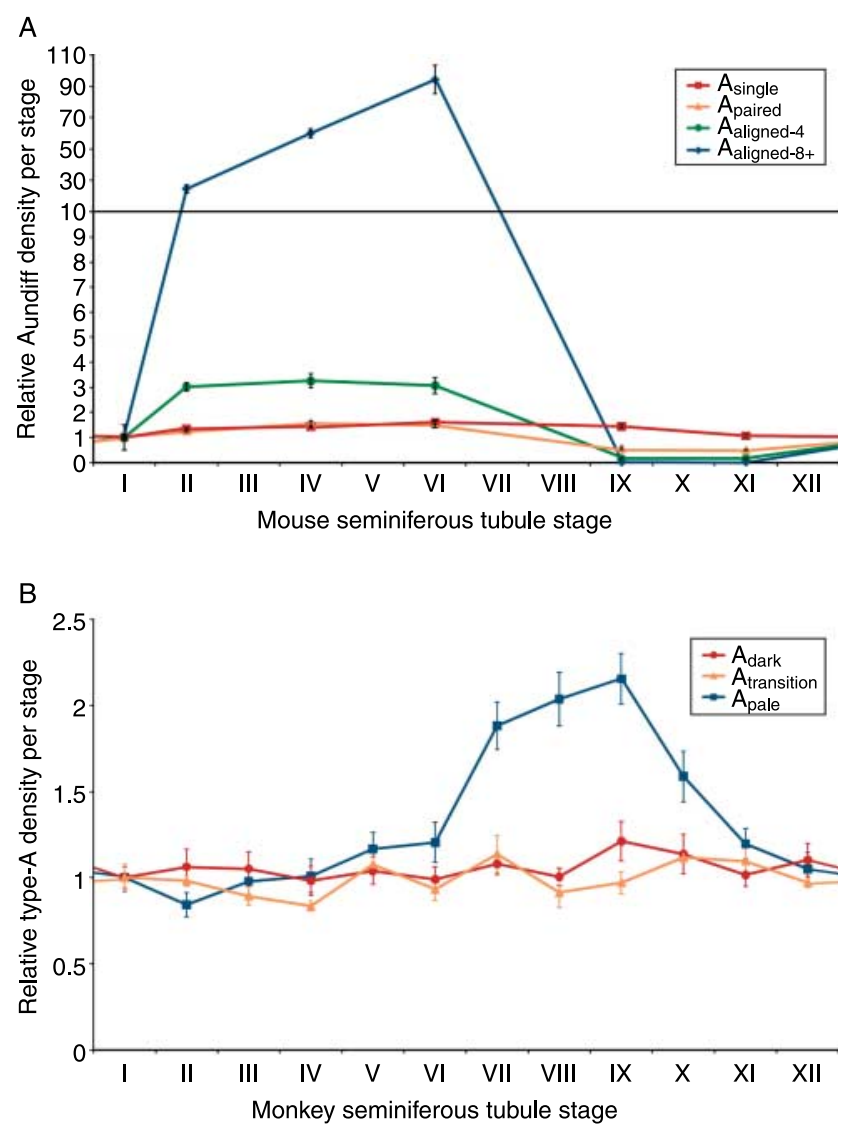

Figure 1 Relative distribution of undifferentiated type-A spermatogonia in mice and monkeys. The relative number of undifferentiated spermatogonia in any given segment of seminiferous tubules at each stage of the seminiferous cycle is shown for (A) mice (Tegelenbosch \& de Rooij 1993) and (B) monkeys (Fouquet \& Dadoune 1986). For A, data for the relative number of $A_{\text {single }}$ (red squares, line), $A_{\text {paired }}$ (orange triangles, line), and $\mathrm{A}_{\text {aligned }}$ clones of 4 and $8+$ cells (green circles, blue diamonds) are shown for $\mathrm{C} 3 \mathrm{H}-101 \mathrm{~F} 1$ hybrid mice (Tegelenbosch \& de Rooij 1993). The calculated relative density of undifferentiated type-A spermatogonia at each stage was determined by dividing the value for each stage (number of spermatogonia per 1000 Sertoli cells) by the same value for stage I (Tegelenbosch \& de Rooij 1993). In B, data for the relative density of $A_{\text {dark, }}, A_{\text {transition, }}$ and $A_{\text {pale }}$ per stage are as reported for cynomolgus monkeys (Fouquet \& Dadoune 1986).

The calculated relative density of type-A spermatogonia in each stage (number of spermatogonia per 100 Sertoli cells) was normalized to the value for stage I (Fouquet \& Dadoune 1986).

between stages (Fig. 1B, orange line; Fouquet \& Dadoune 1986). In contrast, $A_{\text {pale }}$ numbers are not constant due to their more active stage-dependent proliferation resulting in peak numbers at mid-cycle (stages VII-VIII) and a nadir late in the cycle (stages X-XII) (Fig. 1B, blue line; Fouquet \& Dadoune 1986). $A_{\text {pale }}$ divide between stages VII and IX of the seminiferous epithelium (Clermont 1969, Clermont \& Antar 1973, Fouquet \& Dadoune 1986, Ehmcke et al. 2005b, Simorangkir et al. 2009), although there is disagreement in the literature about whether $A_{\text {pale }}$ divide once
(Clermont \& Leblond 1959, Clermont 1969, Simorangkir et al. 2009) or twice (Clermont \& Antar 1973, Ehmcke et al. 2005a) during a cycle of the seminiferous epithelium. The profile of rhesus $A_{\text {pale }}$ numbers across the cycle of the seminiferous epithelium (Fig. 1B, blue line) appears more similar to mouse $A_{\text {aligned }}$ spermatogonia (Fig. 1A, green and blue lines), although there appears to be a difference between species in the timing of divisions.

There is limited information about the clonal arrangement of $A_{\text {dark }}$ and $A_{\text {pale }}$ spermatogonia in nonhuman primate seminiferous. Clermont \& Leblond (1959) first reported pairs and 'quartets' of $A_{\text {dark }}$ and $A_{\text {pale }}$ spermatogonia using maps of rhesus macaque spermatogonia from individual seminiferous tubules generated by plotting the relative positions of spermatogonia in numerous serial testis sections. Using the camera lucida technique, Clermont (1969) subsequently reported the clonal arrangement of $A_{\text {dark }}$ and $A_{\text {pale }}$ spermatogonia in hematoxylin-stained segments of intact seminiferous tubules from adult vervet monkeys (Cercopithecus aethiops). This approach enabled the visualization of $A_{\text {dark }}$ and $A_{\text {pale }}$ spermatogonia and their topological arrangement. Clermont concluded from these studies that $A_{\text {dark }}$ and $A_{\text {pale }}$ existed only as clearly demarcated even-numbered clusters, with the highest frequency being pairs $(20.7 \%)$ and groups of $4(40.7 \%)$. It is difficult to draw any broad conclusions about the clonal organization of $A_{\text {dark }}$ and $A_{\text {pale }}$ in primates using these spermatogonial map and camera lucida data for two reasons. First, intercellular cytoplasmic bridges, which would definitively identify clones, are not reproduced in camera lucida drawings. Secondly, topographical guidelines to help establish clonality, such as the $25 \mu \mathrm{m}$ criteria employed later in rodents (see Huckins 1971), were not applied to these camera lucida analyses.

de Rooij and colleagues reported that clonal arrangement of type-A spermatogonia in seminiferous tubules recovering after low-dose radiation in a large number of rhesus macaques (van Alphen et al. 1988). Clonal analysis was performed using morphological and topographical criteria similar to those employed for rodents (Huckins 1971, Oakberg 1971, de Rooij 1973). Results in the repopulating seminiferous epithelium demonstrated clones of $1,2,4,8$, and $\geq 16$ of both $A_{\text {dark }}$ and $A_{\text {pale }}$ (van Alphen et al. 1988), but it is not clear whether these data equate to the normal clonal arrangement of spermatogonia during steady-state spermatogenesis. As proposed recently, the clonal arrangement of $A_{\text {dark }}$ and $A_{\text {pale }}$ in primate testes during steady-state spermatogenesis may relate to whether these cells exhibit functional identity as stem cells or progenitor spermatogonia (reviewed by Ehmcke \& Schlatt (2006) and Ehmcke et al. (2006)). The observation that isolated, single spermatogonia in S-phase were exceedingly rare in the rhesus testis prompted the theory that there are many nonproliferating single type-A 
spermatogonia, which may be $A_{\text {dark }}$ spermatogonia (Ehmcke et al. 2005b). Thus, additional studies are needed to clarify the kinetics of type-A spermatogonial expansion in primates, including defining $A_{\text {dark }}$ and $A_{\text {pale }}$ clone size as it relates to the stage of the seminiferous epithelium.

\section{Kinetics of type-A spermatogonial proliferation in primate testes}

In support of the 'reserve stem cell' model discussed above, a few studies have proposed mechanisms for how $A_{\text {pale maintain spermatogenesis in the absence of }}$ significant $A_{\text {dark }}$ proliferation. Based on morphometric evaluation in the vervet monkey, Clermont (1969) reported that all $A_{\text {pale }}$ divide between stages IX and $X$ of the seminiferous epithelium. Half of the daughter population remains as $A_{\text {pale }}$ (self-renews) and the other half differentiates to B1 spermatogonia (Clermont 1969). In the stump-tailed macaque (Macaca arctoides), Clermont observed two divisions of $A_{\text {pale }}$ in each cycle of the seminiferous epithelium. A doubling $A_{\text {pale }}$ division occurs at stage VII, and a second differentiating division occurs at stage IX to produce B1 spermatogonia (Clermont 1972, Clermont \& Antar 1973). Similarly, using whole mount preparations of rhesus seminiferous tubules, Ehmcke et al. (2005a) observed two mitotic $A_{\text {pale }}$ events per cycle and proposed a 'clone splitting' model of $A_{\text {pale }}$ renewal and differentiation. In this model, larger clones of $A_{\text {pale }}$ (e.g. eight cells) produced after the first division at stage VII disintegrate into multiple smaller $A_{\text {pale }}$ clones (e.g. two clones of two $A_{\text {pale }}$ and one clone of four $A_{\text {pale }}$ ) that will again divide (at stage IX) to form clones of four or eight B1 spermatogonia or more clones of eight $A_{\text {pale }}$ (self-renewal). These models attempt to explain how $A_{\text {pale }}$ spermatogonia might balance self-renewing and differentiating divisions to maintain spermatogenesis with little contribution from $A_{\text {dark }}$.

Work from the de Rooij laboratory provided evidence that $A_{\text {dark }}$ are mobilized following cytotoxic insult to the testis (van Alphen \& de Rooij 1986). During the first 11 days after $X$-irradiation of rhesus testes, these investigators observed a near depletion of $A_{\text {pale }}$ spermatogonia, with no significant change in the number of $A_{\text {dark }}$. A significant decrease in $A_{\text {dark }}$ spermatogonia was observed 14 days after $X$-irradiation with a corresponding increase in $A_{\text {pale }}$ spermatogonia. The authors concluded that the resting $A_{\text {dark }}$ were activated into proliferating $A_{\text {pale }}$ spermatogonia (van Alphen \& de Rooij 1986). Thus, $A_{\text {dark }}$ appear to fulfill the role of a 'reserve stem cell'. However, whether $A_{\text {dark }}$ spermatogonia also participate in steadystate spermatogenesis remains an open question.

Since Clermont's (1969) initial observation that $A_{\text {dark }}$ spermatogonia do not divide, six additional studies have been conducted in various nonhuman primate species to describe the proliferating fraction of type-A spermatogonia (Table 2). Four of the five studies observed ${ }^{3} \mathrm{H}$-thymidine or $\mathrm{BrdU}$ label in $\mathrm{A}_{\text {dark }}$ spermatogonia within a few hours and/or several days after the administration of a pulse label (Clermont \& Antar 1973, Kluin et al. 1983, Fouquet \& Dadoune 1986, Ehmcke et al. 2005b, Simorangkir et al. 2009). Similar to Clermont's observation in the vervet monkey, Simorangkir et al. (2009) did not observe labeling in $A_{\text {dark }}$. However, these investigators observed labeling in a new 'unclassified' category of type-A spermatogonia $\left(A_{\text {unc }}\right)$, which they acknowledged might be classified as $A_{\text {dark }}$ by other investigators. It is not clear whether $\mathrm{A}_{\text {unc }}$ are the same cells as those previously defined with an intermediate phenotype as A-transition $\left(A_{t}\right)$, some of which also label with ${ }^{3} \mathrm{H}$-thymidine (Fouquet \& Dadoune 1986). Immunohistochemistry for the proliferating cell nuclear antigen (PCNA) has also determined that rhesus and human $A_{\text {dark }}$ spermatogonia failed to label, while only a fraction of $A_{\text {pale }}$ in late stages of the cycle of the seminiferous epithelium were $\mathrm{PCNA}^{+}$(Schlatt \& Weinbauer 1994). Considering the lack of consensus about the cell cycling characteristics of $A_{\text {dark }}$ spermatogonia, additional studies are needed to confirm whether 1) $A_{\text {dark }}$ are quiescent and serve as reserve stem spermatogonia or 2) $A_{\text {dark }}$ divide with sufficient (albeit low) frequency to maintain spermatogenesis under normal, steady-state conditions.

The $A_{\text {dark }} / A_{\text {pale }}$ 'reserve stem cell' model of nonhuman primate SSCs is very similar to the $A_{0} / A_{1}$ 'reserve stem cell' model that was originally advanced for rodents (Clermont \& Bustos-Obregon 1968, Dym \& Clermont 1970, Clermont \& Hermo 1975, Bartmanska \& Clermont 1983). However, this model was supplanted by an alternative model (Huckins 1971, Oakberg 1971), in which there is a single population of stem cells $\left(A_{\text {single }}\right.$ spermatogonia) that divides regularly, but infrequently, and gives rise to the entire spermatogenic lineage. This $\mathrm{A}_{\text {single }}$ model has gained wide (but not universal) acceptance in the field. Spermatogenesis is highly conserved (Fritz 1986), and thus, it is tempting to extrapolate results from the studies of rodent SSCs to primates.

The identity, characteristics, and behavior of primate SSCs, however, must be determined experimentally. As reviewed above, rodent SSCs can be identified using three approaches: 1) transplantation to observe functional capacity to establish and maintain spermatogenesis (Ogawa et al. 1997, Nagano \& Brinster 1998), 2) molecular phenotype (expression of some or all of a battery of specific molecular markers), and 3) clonal arrangement ( $A_{\text {single; }}$ de Rooij \& Russell 2000). Until recently, almost nothing was known about SSCs in primate testes. Progress in the last few years has begun to address this deficit using rhesus-to-nude mouse xenotransplantation, molecular phenotyping of spermatogonia, and clonal analysis of spermatogonia in whole mount aided by immunohistochemistry. 
Table 2 Experimental evidence for $A_{\text {dark }}$ and $A_{\text {pale }}$ proliferation.

\begin{tabular}{|c|c|c|c|c|c|c|c|}
\hline Study & Species $^{\mathrm{a}}$ & Label & $\begin{array}{l}\text { Animals, } \\
\text { X-sections }\end{array}$ & $\begin{array}{l}\text { Time to } \\
\text { analysis }\end{array}$ & $\begin{array}{l}\text { Percentage of } \\
\mathbf{A}_{\text {dark }} \text { labeled } \\
\text { (stage) }\end{array}$ & $\begin{array}{l}\text { Percentage of } \\
A_{\text {pale labeled }} \\
\text { (stage) }\end{array}$ & $\begin{array}{l}\text { Percentage of } \\
\mathbf{A}_{\mathbf{t}} / \mathbf{A}_{\text {unc }} \text { labeled } \\
(\text { stage })\end{array}$ \\
\hline Clermont (1969) & $\begin{array}{l}\text { Cercopithecus } \\
\text { aethiops }\end{array}$ & ${ }^{3} \mathrm{H}$-Thy & $1, \mathrm{~N} / \mathrm{A}$ & $2.5 \mathrm{~h}$ & 0 & $36.1 \%(\mathrm{VII}-\mathrm{X})$ & $\mathrm{N} / \mathrm{A}$ \\
\hline $\begin{array}{l}\text { Clermont \& Antar } \\
\text { (1973) }\end{array}$ & $\begin{array}{l}\text { Macaca } \\
\text { arctoides }\end{array}$ & ${ }^{3} \mathrm{H}$-Thy & $3, \geq 400$ & $3 \mathrm{~h}$ & 0.06-0.09 (VII-X) & 25.6-41.9 (VII-X) & $\mathrm{N} / \mathrm{A}$ \\
\hline Kluin et al. (1983) & $\begin{array}{l}\text { Macaca } \\
\quad \text { fascicularis }\end{array}$ & ${ }^{3} \mathrm{H}-\mathrm{Thy}^{\mathrm{c}}$ & $\begin{array}{l}4, \geq 400 \\
5,60\end{array}$ & $\begin{array}{l}12 \text { days } 3 \mathrm{~h} \\
1 \mathrm{~h}^{\mathrm{c}}\end{array}$ & $\begin{array}{l}0 \\
1.5 \text { (9 of } \sim 600 \\
\text { cells) }\end{array}$ & $\begin{array}{l}5.9-11.8(\mathrm{VII}-\mathrm{X}) \\
14.9(88 \text { of } \sim 591 \\
\text { cells) }\end{array}$ & $\begin{array}{l}\text { N/A } \\
\text { N/A }\end{array}$ \\
\hline $\begin{array}{l}\text { Fouquet \& Dadoune } \\
\text { (1986) }\end{array}$ & $\begin{array}{l}\text { Macaca } \\
\text { fascicularis }\end{array}$ & ${ }^{3} \mathrm{H}$-Thy ${ }^{d}$ & 2,800 & $1 \mathrm{~h}$ & 0 & 4-34 (VI-IX) & $0.5-2.2 \mathrm{~A}_{\mathrm{t}}(\mathrm{VII}-\mathrm{IX})$ \\
\hline \multirow[t]{2}{*}{$\begin{array}{l}\text { Schlatt \& } \\
\quad \text { Weinbauer (1994) }\end{array}$} & Macaca mulata & PCNA & $\begin{array}{l}2,800 \\
2,1.5 \times \\
\quad 10^{6} \mu \mathrm{m}^{2}\end{array}$ & $\begin{array}{l}9-10 \text { days } \\
\text { N/A }\end{array}$ & $\begin{array}{l}2.3-10.8 \text { (IV-IV) } \\
0\end{array}$ & $\begin{array}{l}8.4-47.6 \text { (IV-IX) } \\
\text { X-XI only }\end{array}$ & $\begin{array}{l}2.9-36.3 \mathrm{~A}_{\mathrm{t}}(\mathrm{V}-\mathrm{VIII}) \\
\mathrm{N} / \mathrm{A}\end{array}$ \\
\hline & Homo sapiens & PCNA & 2 , not indicated & N/A & 0 & V only & N/A \\
\hline $\begin{array}{l}\text { Ehmcke et al. } \\
\qquad(2005 a, 2005 b)\end{array}$ & Macaca mulata & BrdU & $4, N / A^{e}$ & $3 \mathrm{~h}$ & $\begin{array}{l}0.77 \text { or } 18.39 \\
\left(^{(a l l ~ s t a g e s)}{ }^{f}\right.\end{array}$ & 27.52 (VII only) & $\mathrm{N} / \mathrm{A}$ \\
\hline \multirow{2}{*}{$\begin{array}{l}\text { Simorangkir et al. } \\
\text { (2009) }\end{array}$} & Macaca mulata & BrdU & $4, N / A^{g}$ & $3 \mathrm{~h}$ & $0(\mathrm{IV}-\mathrm{IX})$ & 〜13-24 (VI-XII) & $\sim 2 \%(\mathrm{VI}-\mathrm{XII}) \mathrm{A}_{\mathrm{unc}}$ \\
\hline & & & $4, N / A^{g}$ & 11 days $3 \mathrm{~h}$ & 0 & Yes $(\text { VII-X) })^{\mathrm{h}}$ & Yes $(\mathrm{VI}-\mathrm{XI}) \mathrm{A}_{\mathrm{unc}}{ }^{\mathrm{h}}$ \\
\hline
\end{tabular}

${ }^{a}$ Cercopithecus aethiops, vervet monkey; Macaca arctoides, stump-tailed macaque; Macaca fascicularis, cynomolgus monkey (aka: crab-eating monkey, java monkey, Macaca irus); Macaca mulata, rhesus monkey. ${ }^{\mathrm{b}}$ Number of seminiferous tubule cross sections is noted per animal evaluated if available. ${ }^{\mathrm{C}}$ Testicular fragments $\left(1-8 \mathrm{~mm}^{3}\right)$ were incubated in medium containing ${ }^{3} \mathrm{H}$-thymidine for $1 \mathrm{~h}$ at $32{ }^{\circ} \mathrm{C}$ after a 30 min equilibration period. ${ }^{\mathrm{d}}$ Label was administered into the testicular artery followed by two intratesticular injections of label at positions $2 \mathrm{~cm}$ apart. Biopsy at $1 \mathrm{~h}$ recovered tissue at one intratesticular injection site, hemicastration at 9-10 days was used to remove tissue at second injection site. ${ }^{\mathrm{e}}$ Although the precise number of seminiferous cross sections was not reported, the number of microscopic fields was reported per animal (not discriminating between the two analysis points). Spermatogenesis of two animals included in this study was maintained by exogenous gonadotropin administration following a GNRH clamp for a separate study. ${ }^{\mathrm{f}} \mathrm{A}_{\text {dark }}$ labeling was classified as weak and strong, representing the two values noted respectively. ${ }^{\mathrm{g}} \mathrm{Numbers}$ of seminiferous tubule cross sections were not reported, but 1053-1299 cells of each type were evaluated per testis. hThe labeling index of these cells was not reported at 11 days $3 \mathrm{~h}$ after label administration.

\section{An assay for studying primate SSCs}

In rodents, SSC transplantation is the experimental 'gold standard' for detecting SSC activity because it demonstrates that a cell has the biological capacity to initiate and maintain spermatogenesis by balancing self-renewal and differentiation (Brinster \& Avarbock 1994, Brinster \& Zimmermann 1994). While this functional assay has been a powerful tool for characterizing SSCs in rodents, monkey-to-monkey SSC transplantation as a routine biological assay is not feasible. Nonhuman primates are a limited resource, and studies on these large animals are confounded by their large size, long lifespan, high cost, and variability among outbred individuals. Pioneering work from the Brinster, de Rooij, Dobrinski, and Griswold laboratories, however, provided the proofin-principle that SSCs from a variety of species can be transplanted to the testes of immune-deficient nude mice where they migrate to the seminiferous tubule basement membrane and proliferate to form chains of spermatogonia that persist long term (Clouthier et al. 1996, Dobrinski et al. 1999a, 2000, Ogawa et al. 1999, Nagano et al. 2001b, 2002, Honaramooz et al. 2002, Oatley et al. 2002, Izadyar et al. 2003). Germ cells from closely related species (e.g. mouse, rat, and hamster) produce chains or networks of spermatogonia by 2 weeks after transplantation (Fig. 2A and B), which give rise to extensive colonies of complete spermatogenesis by 2 months (Fig. 2C and D). In contrast, germ cells from primate species including rhesus macaques (Fig. 2E and F; Hermann et al. 2007, 2009), baboons (Nagano et al. 2001b), and humans (Fig. 2G and H; Nagano et al. 2002) produce chains and patches of spermatogonia, similar to rodent colonies at 2 weeks, but do not produce complete spermatogenesis. The ability of mouse Sertoli cells to support the early stages of spermatogenesis from distantly related species represents remarkable evolutionary conservation. These patches of spermatogonia are maintained long term and have been observed for several months to a year after transplantation (Nagano et al. 2001b, 2002, Hermann et al. 2007, 2009). As detailed below, these rudimentary spermatogonial patches in the xenotransplant paradigm may constitute an experimentally tractable bioassay for primate SSCs.

To enable this xenotransplant assay, immune-deficient nude mice are treated with busulfan to eliminate endogenous spermatogenesis as described previously (Brinster \& Avarbock 1994, Brinster \& Zimmermann 1994). Donor testis cell suspensions can be generated by two-step enzymatic digestion (Bellve et al. 1977, Hermann et al. 2007) and transplanted into seminiferous tubules of nude mouse recipient testes by efferent duct injection (Nagano et al. 2001b, 2002, Hermann et al. 2007, Maki et al. 2009). Donor-derived patches of 

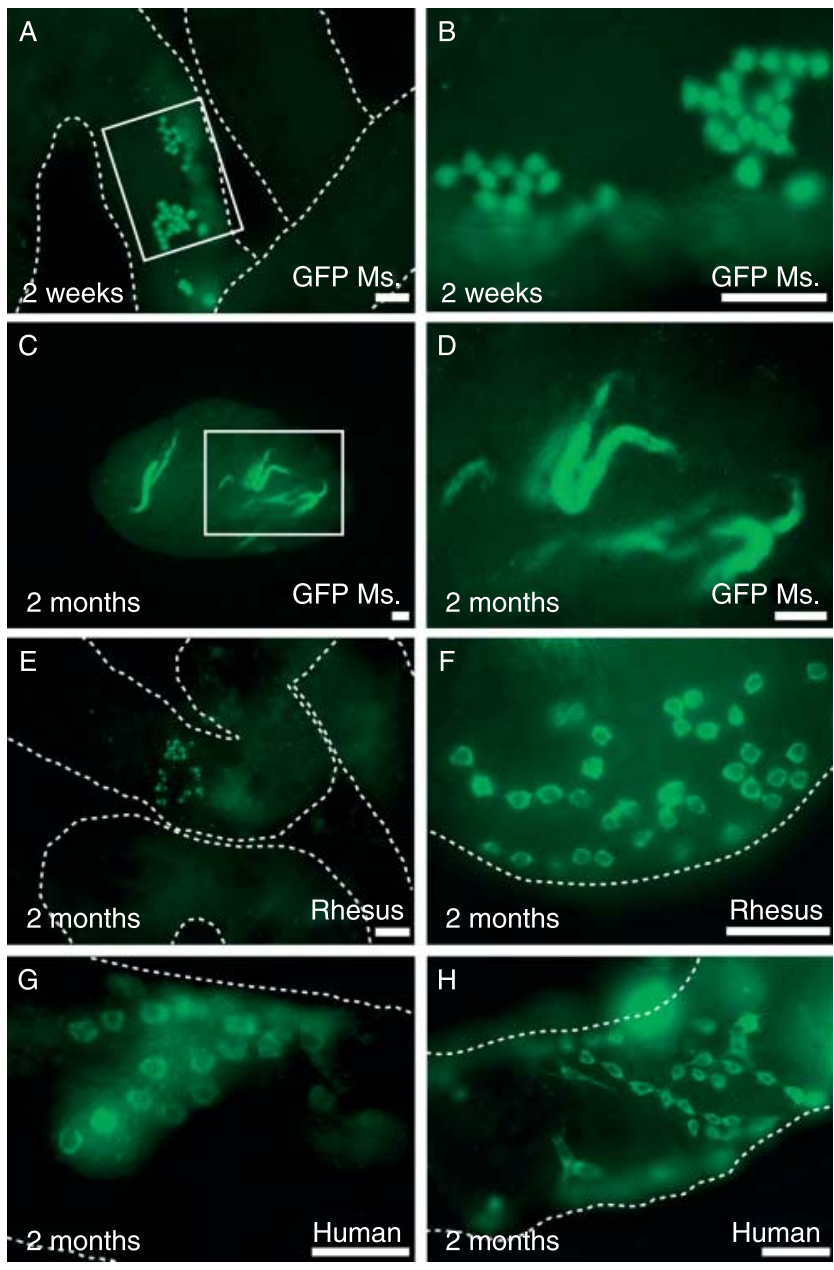

Figure 2 SSC transplantation from different donor species into busulfantreated mouse testes. (A and B) Donor GFP mouse testis cells (green) at 2 weeks after transplantation. Margins of recipient seminiferous tubules are marked by a dashed white line. (C and D) Donor GFP mouse testis cells (green) at 2 months after transplantation. Patches of transplanted donor ( $\mathrm{E}$ and $\mathrm{F}$ ) rhesus and $(\mathrm{G}$ and $\mathrm{H})$ human testis cells in immunedeficient nude mouse seminiferous tubules were detected by whole mount immunohistochemistry using the rhesus testis cell antibody. Scale bars $=50 \mu \mathrm{m}$. Adapted from Hermann et al. $(2007,2009)$ and unpublished data.

spermatogonia can be identified 1-2 months after transplantation by staining with a donor species-specific antiserum as described previously (Nagano et al. 2001b, 2002, Hermann et al. 2007, 2009). Alternatively, donor testis cells can be preloaded with a fluorescent marker (e.g. PKH26 or CFDA) prior to transplantation (Honaramooz et al. 2002, Maki et al. 2009). With the fluorescent loading approach, recipient testes are typically analyzed within 2-3 weeks after transplantation to minimize the dilution of the fluorescent dye through cell divisions.

While evolutionary distance between primates and mice presumably precludes the establishment of complete spermatogenesis in the xenotransplant assay, colonization foci consisting of spermatogonial patches exhibit several features of SSCs. They arise from transplanted cells that migrate to the basement membrane of recipient seminiferous tubules and produce chains of spermatogonia that persist long term (Nagano et al. 2001b, 2002, Hermann et al. 2007, 2009). For our studies in rhesus macaques, we have defined SSC-derived spermatogonial patches as four or more cells in discrete patches (without a gap of $\geq 100 \mu \mathrm{m}$ between adjacent cells) on the basement membrane of recipient mouse seminiferous tubules that exhibit characteristic spermatogonial features (i.e. ovoid shape with high nuclear to cytoplasmic ratios). Nagano et al. $(2001 b, 2002)$ used similar criteria for baboon and human SSCs, but defined patches as containing ten or more cells within a $150 \mu \mathrm{m}$ length of seminiferous tubule. Co-staining for VASA or RBMY has been used to confirm that the xenotransplant spermatogonial patches were composed of germ cells (Nagano et al. 2001b, Hermann et al. 2007). However, it is important to interpret xenotransplant results cautiously because some donor cell foci fail to exhibit spermatogonial features, and therefore, are not considered to arise from stem cells (Hermann et al. 2007). As more information becomes available, it may be reasonable to revise the criteria for defining spermatogonial patches in the xenotransplant assay.

Using the criteria detailed above, we employed rhesus-to-nude mouse xenotransplantation to characterize SSC activity in adult rhesus testes. Analysis of nude mouse recipient seminiferous tubules 2 months after transplantation revealed that 4.64 patches $/ 10^{6}$ viable donor adult rhesus testis cells transplanted (Hermann et al. 2007). In contrast, testis cells from males treated with busulfan ( 8 or $12 \mathrm{mg} / \mathrm{kg}$ ) failed to produce any patches of spermatogonia. These data suggested that high-dose alkylating chemotherapy caused depletion of SSCs in rhesus testes, consistent with previous observations for mice (Kanatsu-Shinohara et al. 2003, Orwig et al. 2008). In a separate study, the xenotransplant assay demonstrated that spermatogonial patches were enriched in the $\mathrm{THY} 1^{+}$fraction of rhesus testis cells (Hermann et al. 2009), with corresponding depletion in $\mathrm{THY}^{-}$rhesus testis cells, similar to observations of mouse and rat SSCs (Kubota et al. 2003, Ryu et al. 2004). Evolutionary conservation of these biological readouts provides a partial validation of the xenotransplantation assay (Hermann et al. 2007, 2009). Maki et al. (2009) have also utilized the xenotransplant technique and reported enhanced colonizing activity in an SSEA4 ${ }^{+}$subpopulation of rhesus testis cells. Continued FACS and xenotransplantation experiments will enable the systematic characterization of primate SSCs and potentially lead to enrichment strategies with implications for future SSC-based treatments of male infertility. 


\section{Marker analysis for functional categorization of rhesus spermatogonia and identification of the putative stem cell pools}

Until recently, little was known about the molecular characteristics of nonhuman primate spermatogonia, including SSCs. This contrasts with rodents, where decades of studies provide an extensive molecular phenotype of cell surface, cytoplasmic, and nuclear proteins that are expressed by rodent SSCs. Although no SSC-specific marker has been identified to date for any species, the combined expression profiles of multiple markers provide composite phenotypic information about stem, progenitor, and differentiating spermatogonia in rodents that may be used to identify similar cells in other species, including primates. To this end, several recent studies have evaluated nonhuman primate testes for the expression of various proteins known to mark
SSCs and other stem cells (reviewed in Table 3). However, there is limited information about how these markers correlate with spermatogenic cell types in primates (e.g. $A_{\text {dark, }} A_{\text {pale, }}$ and B spermatogonia).

In order to bridge the gap between molecular phenotype data and spermatogenic cell types, we recently investigated expression of rodent spermatogonial markers (GFRA1, PLZF, NGN3, and KIT) in the rhesus testis and related our findings to classical descriptions of nuclear morphology (i.e. $A_{\text {dark, }} A_{\text {pale, }}$ and $B$ spermatogonia; Fig. 3A-E; Hermann et al. 2009). The expression profile of each marker in the rhesus testis was correlated with the functional categories of rodent spermatogonia exhibiting similar phenotypes, including stem $\left(\mathrm{A}_{\text {single }}\right.$ and some $\mathrm{A}_{\text {pairedi }} \mathrm{GFRA} 1^{+}, \mathrm{PLZF}^{+}$, $\mathrm{NGN}^{+/-}$, and $\mathrm{KIT}^{-}$), transit-amplifying progenitor (some $\mathrm{A}_{\text {paired }}$ and $\mathrm{A}_{\text {alignedi }}$ GFRA1 ${ }^{+}, \mathrm{PLZF}^{+}, \mathrm{NGN3}^{+}$, and $\left.\mathrm{KIT}^{+/}\right)$, and differentiating (A1-4, intermediate,

Table 3 Molecular markers of germ cells and spermatogonial stem cells expressed in nonhuman primate testes.

\begin{tabular}{|c|c|c|c|c|c|c|}
\hline \multirow[b]{2}{*}{ Marker (aliases) } & \multirow[b]{2}{*}{ References } & \multirow[b]{2}{*}{ Species $^{\mathrm{a}}$} & \multirow[b]{2}{*}{ Approach } & \multirow{2}{*}{$\begin{array}{l}\text { Expressed in } \\
\text { spermatogonia? }\end{array}$} & \multicolumn{2}{|c|}{ Overlap with } \\
\hline & & & & & $A_{\text {dark }}$ & $A_{\text {pale }}$ \\
\hline \multirow[t]{2}{*}{$\mathrm{KIT}(\mathrm{cKIT})$} & Hermann et al. (2009) & Macaca mulata & IHC & Yes & $0 \%$ & $22.8 \%$ \\
\hline & Maki et al. (2009) & Macaca mulata & FCM & ND & ND & ND \\
\hline DAZL & Hermann et al. (2007) & Macaca mulata & $\mathrm{IHC}$ & $\begin{array}{l}\text { Staining weak/absent } \\
\text { in spermatogonia }\end{array}$ & ND & ND \\
\hline \multirow[t]{3}{*}{ GFRA1 (GFR $\alpha 1)$} & Hermann et al. (2007) & Macaca mulata & IHC & Rare $\mathrm{BM}$ cells ${ }^{\mathrm{b}}$ & ND & ND \\
\hline & Hermann et al. (2009) & Macaca mulata & $\mathrm{IHC}$ & Yes & $100 \%$ & $100 \%$ \\
\hline & Maki et al. (2009) & Macaca mulata & $\mathrm{ICC} / \mathrm{IHC}$ & Rare BM cells ${ }^{\mathrm{b}}$ & ND & ND \\
\hline $\begin{array}{l}\alpha 6 \text {-INTEGRIN } \\
\text { (INTGA6) }\end{array}$ & Maki et al. (2009) & Macaca mulata & FCM+ICC/XenoTP & Yes $^{c}$ & ND & ND \\
\hline MAGEA4 & Mitchell et al. (2008) & Callithrix jacchus & IHC & $\begin{array}{l}\text { Yes in } 0-6 \text { weeks } \\
\text { testis }\end{array}$ & ND & ND \\
\hline NANOS1 & Mitchell et al. (2008) & Callithrix jacchus & IHC & $\begin{array}{l}\text { Yes in 0-6 weeks } \\
\text { testis }\end{array}$ & ND & ND \\
\hline NGN3 (NEUROG3) & Hermann et al. (2009) & Macaca mulata & $\mathrm{IHC}$ & Yes & $0 \%$ & $48.5 \%$ \\
\hline POU5F1 (OCT-4) & Mitchell et al. (2008) & Callithrix jacchus & $\mathrm{IHC}$ & $\begin{array}{l}\text { Rare cells in } 0-6 \\
\text { weeks testis }\end{array}$ & ND & ND \\
\hline \multirow[t]{2}{*}{ PLZF (ZBTB16) } & Hermann et al. (2007) & Macaca mulata & IHC & Rare BM cells ${ }^{b}$ & ND & ND \\
\hline & Hermann et al. (2009) & Macaca mulata & IHC & Yes & $82 \%$ & $100 \%$ \\
\hline \multirow[t]{4}{*}{ SSEA4 } & Muller et al. (2008) & Macaca mulata & $\mathrm{IHC}$ & Rare BM cells ${ }^{\mathrm{b}}$ & ND & ND \\
\hline & Muller et al. (2008) & Macaca silenus & $\mathrm{IHC}$ & Rare BM cells ${ }^{b}$ & ND & ND \\
\hline & Muller et al. (2008) & Callithrix jacchus & $\mathrm{IHC}$ & Rare BM cells ${ }^{b}$ & ND & ND \\
\hline & Maki et al. (2009) & Macaca mulata & FCM+ICC/XenoTP & Yes $^{\mathrm{c}}$ & ND & ND \\
\hline SALL4 & $\begin{array}{l}\text { Hermann, Marshall \& } \\
\text { Orwig unpublished }\end{array}$ & Macaca mulata & $\mathrm{IHC}$ & Yes & Yes & Yes \\
\hline \multirow{2}{*}{ THY1 (CD90) } & Maki et al. (2009) & Macaca mulata & FCM+ICC/XenoTP & $Y s^{c}$ & ND & ND \\
\hline & Hermann et al. (2009) & Macaca mulata & $\begin{array}{l}\text { FCM+ICC/qPCR/ } \\
\text { XenoTP }\end{array}$ & Yes $^{\mathrm{d}}$ & ND & ND \\
\hline \multirow[t]{3}{*}{ TRA-1-81 } & Muller et al. (2008) & Macaca mulata & $\mathrm{IHC}$ & Rare BM cells ${ }^{b}$ & ND & ND \\
\hline & Muller et al. (2008) & Macaca silenus & $\mathrm{IHC}$ & Rare BM cells ${ }^{\mathrm{b}}$ & ND & ND \\
\hline & Muller et al. (2008) & Callithrix jacchus & IHC, FCM & Rare BM cells ${ }^{\mathrm{b}}$ & ND & ND \\
\hline \multirow[t]{3}{*}{ VASA (DDX4) } & Hermann et al. (2007) & Macaca mulata & IHC & Weak in adult & ND & ND \\
\hline & Mitchell et al. (2008) & Callithrix jacchus & $\mathrm{IHC}$ & $\begin{array}{l}\text { Yes in 0-6 weeks } \\
\text { testis }\end{array}$ & ND & ND \\
\hline & Hermann et al. (2009) & Macaca mulata & $\mathrm{IHC}$ & Yes in juvenile & $100 \%$ & $100 \%$ \\
\hline
\end{tabular}

IHC, immunohistochemistry; FCM, flow cytometry/fluorescence-activated cell sorting; XenoTP, xenotransplantation; ICC, immunocytochemistry; qPCR, quantitative PCR.

${ }^{a}$ Macaca mulata, rhesus monkey; Macaca silenus, lion-tailed macaque; Callithrix jacchus, common marmoset. ${ }^{\text {b }}$ Rare cells positive for the marker located on the basement membrane of testicular seminiferous tubule cross sections. 'Expression by spermatogonia determined by immunocytochemical staining for GFRA1 in sorted fractions of adult rhesus testis cells. ${ }^{d}$ Expression by spermatogonia determined by immunocytochemical staining for VASA and qPCR for VASA, GFRA1, and PLZF in juvenile rhesus testis cells sorted for THY1. 

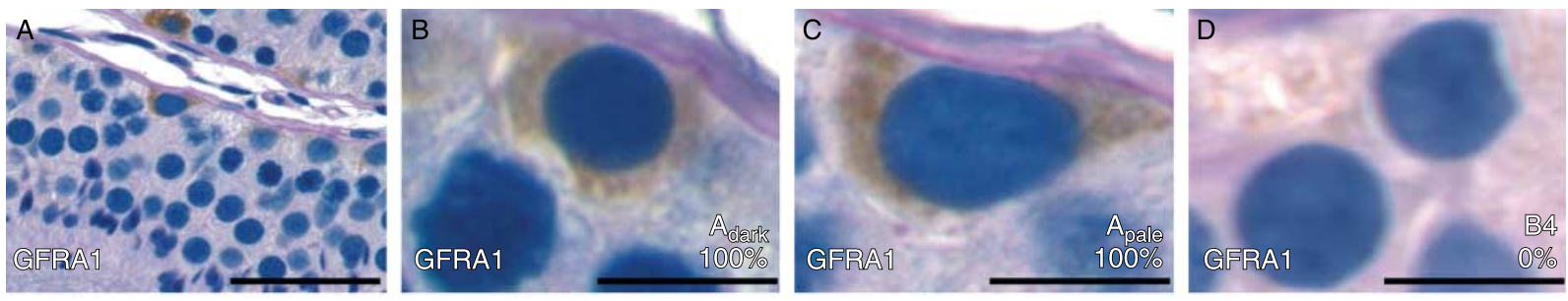

E

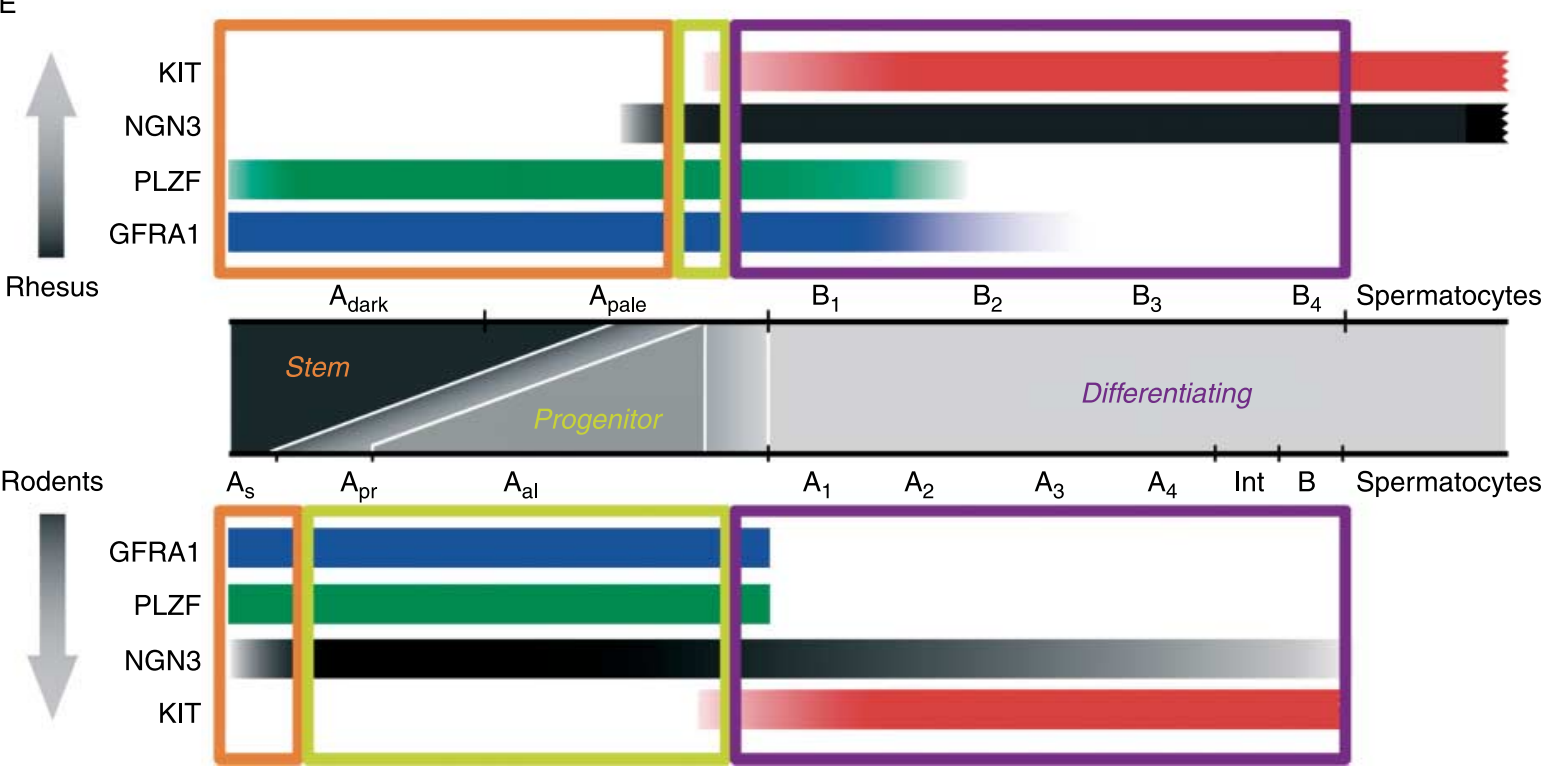

Figure 3 Correlation between molecular markers of rodent SSCs (GFRA1, PLZF, NGN3, and KIT) and morphological descriptions ( $A_{\text {dark }}, A_{\text {pale, }}$ and B) of spermatogonia in the adult rhesus testis. Sections of adult rhesus testes were evaluated by immunohistochemistry for GFRA1, PLZF, NGN3, and KIT (Hermann et al. 2009). Subsequently, sections were counterstained by the PAS-hematoxylin method to reveal nuclear morphology and identify $A_{\text {dark }}$ and $A_{\text {pale }}$ spermatogonia, as well as differentiating type-B spermatogonia. (A and D) Representative staining for GFRA1 is shown. The image in (A) shows part of one seminiferous tubule (scale bar $=50 \mu \mathrm{m}$ ). Enlargements are also shown of representative $A_{\text {dark }}(B), A_{\text {pale }}(C)$, and $B 4$ spermatogonia (D) (scale bar $=10 \mu \mathrm{m}$ ). For all spermatogonia that could be definitively classified as $A_{\text {dark }}$ or $A_{\text {pale, }}$ the percentage that were labeled for GFRA1 is shown. (E) Colored bars (GFRA1, blue; PLZF, green; NGN3, black; KIT, red) indicate the extent of marker expression in the adult spermatogenic lineage based on recently published data (Hermann et al. 2009; rhesus, top) or previously published mouse studies (reviewed in Hermann et al. (2009); mice, bottom). Colored boxes indicate functional descriptors 'stem' (orange), 'progenitor' (yellow), and 'differentiating' (violet), based on rodent data and may identify rhesus spermatogonia with corresponding phenotype and function. The transitions from stem to progenitor or progenitor to differentiating are noted by gradient shading in the middle gray bar between these functional categories. The following abbreviations are used for rodents: $A_{s}, A_{\text {single; }} A_{p r}, A_{\text {paired; }} A_{a l}, A_{\text {aligned. }}$. Adapted from Hermann et al. (2009).

and $\mathrm{B} ; \mathrm{GFRA}^{-}, \mathrm{PLZF}^{-}, \mathrm{NGN}^{+}$, and $\mathrm{KIT}^{+}$). We observed a remarkable degree of evolutionary conservation from rodents to primates in the succession of spermatogonial marker expression and their correlation with differentiation state (Fig. 3E). Assuming that molecular characteristics correlate with function and that these relationships are evolutionarily conserved, it may be possible to identify stem spermatogonia in primates. Note that most $A_{\text {dark }}$ and $\sim 50 \%$ of $A_{\text {pale }}$ in the adult rhesus testis exhibit the phenotype GFRA $1^{+}$, $\mathrm{PLZF}^{+}, \mathrm{NGN}^{-}{ }^{-}$, and $\mathrm{KIT}^{-}$(Fig. 3E). As far as we can ascertain from the literature, this phenotype is restricted to $A_{\text {single }}$ spermatogonia, which most will agree comprise at least part of the stem cell pool in mice. Moreover, since NGN3 marks $11.7 \%$ of functional stem cells in mice as well as $A_{\text {aligned }}$ progenitor spermatogonia (Nakagawa et al. 2007), rhesus $A_{\text {pale }}$ spermatogonia with the phenotype $\mathrm{GFRA}^{+}{ }^{+}, \mathrm{PLZF}^{+}, \mathrm{NGN}^{+}{ }^{+}, \mathrm{KIT}^{-}$ could be either stem or progenitor (shaded as transition cells in Fig. 3E). Lastly, KIT expression begins in longer chain progenitors (i.e. $A_{\text {aligned } 8-16}$ ) in rodents and continues in differentiating types $\mathrm{A} 1-4$ spermatogonia (Schrans-Stassen et al. 1999). Some $A_{\text {pale }}$ in the adult rhesus testis exhibit a transition phenotype (GFRA $1^{+}$, $\mathrm{PLZF}^{+}, \mathrm{NGN}^{+}{ }^{+}, \mathrm{KIT}^{+}$, like longer chain rodent Aaligned; Fig. 3E).

Based on the conservation of molecular markers from rodents to primates, we have proposed that the stem cell pool in the rhesus testis comprises all $A_{\text {dark }}$ and at least $50 \%$ of $A_{\text {pale }}$ spermatogonia, and that 

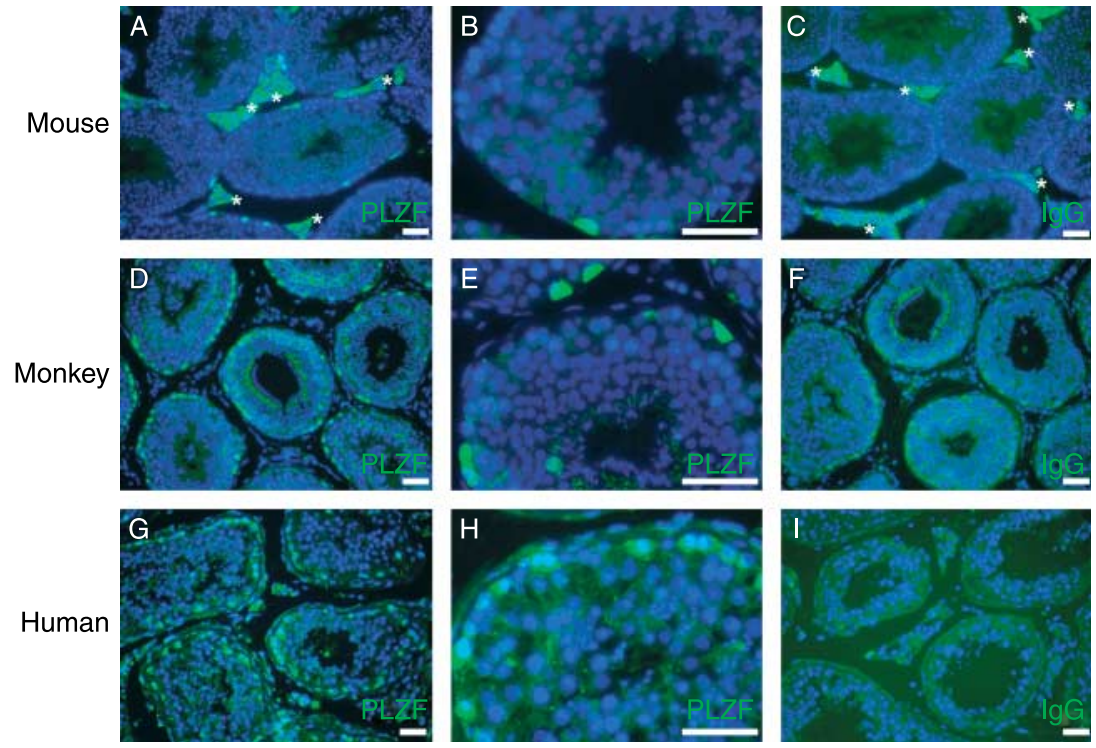

Figure 4 Comparative immunohistochemical analysis reveals species-specific staining profiles for the stem/progenitor marker PLZF. To begin translating knowledge of rodent and monkey SSCs to humans, we have initiated comparative marker analysis using immunohistochemistry for the transcription factor PLZF in sections from (A and B) mouse, (D and E) rhesus macaque, and (G and $\mathrm{H}$ ) human testes. Images of sections incubated with nonimmune isotype control IgGs are also shown for (C) mouse, (F) monkey, and (I) human to demonstrate nonspecific background staining and tissue autofluorescence. White asterisks in $\mathrm{A}$ and $\mathrm{C}$ indicate the nonspecific fluorescent signal observed in interstitial space between seminiferous tubules. Images are shown from (A, C, D, F, G and I) low magnification and (B, D and F) high magnification. PLZF immunoreactivity was observed as a nuclear fluorescent signal (green) in all three species. Sections were counterstained with DAPI (blue). Scale bar $=50 \mu \mathrm{m}$. (BP Hermann, MC Hansel \& KE Orwig, unpublished observations).

the stem cell pool is considerably larger in rhesus than mouse testes (see (Hermann et al. 2009) for detailed discussion). In contrast to the large SSC pool, the relative size of the progenitor pool $\left(\mathrm{GFRA} 1^{+}, \mathrm{PLZF}^{+}\right.$, $\mathrm{NGN}^{+}$, and $\mathrm{KIT}^{-}$) appeared much smaller in adult macaques than in rodents. Thus, it appears that rodents and primates employ different strategies to meet a similar biological demand (adult rodent and adult rhesus testes have similar sperm output per gram of testis per day (Sharpe 1994, Gupta et al. 2000, Thayer et al. 2001)). Rodents may have few SSCs and more transit-amplifying progenitors, while rhesus testes may have more SSCs and fewer transit-amplifying progenitors.

Progress studying SSCs and the spermatogenic lineage in rodents and nonhuman primates has begun to stimulate investigations of the biology and regenerative potential of human SSCs (reviewed by Dym et al. (2009)). One recent study confirmed that $\alpha 6-$ INTEGRIN, CD133, SSEA4, VASA, DAZL, and TSPYL2 are expressed in human testis cells or histological section (Conrad et al. 2008). For this review, we have also conducted a comparative analysis of the consensus SSC marker, PLZF, in mouse (Fig. 4A and B), rhesus monkey (Fig. 4C and D), and human (Fig. 4E and F) testes. PLZF staining in human testes was restricted to a subpopulation of cells on the basement membrane of the seminiferous epithelium (like mouse and monkey), and the frequency of $\mathrm{PLZF}^{+}$cells was more similar to monkey than mouse. Other differences (e.g. expression of POU5F1, TSPY, and KIT) have been reported in marker expression between rodent and human spermatogonia, suggesting phenotypic differences in markers of stem cells and their progeny (see review by Dym et al. (2009)). Perhaps, this suggests that the dynamics of the stem/progenitor spermatogonial pools in humans is similar to monkeys. Additional studies are necessary to elaborate on these findings. For future studies, it appears that human-to-nude mouse xenotransplantation can also be optimized as a bioassay for human SSCs (Nagano et al. 2002; Fig. 2G and H).

\section{Future directions}

The considerable degree of phenotypic similarity between $A_{\text {dark }}$ and $A_{\text {pale }}$ spermatogonia in the adult rhesus testis raises questions about the distinct functional classification of $A_{\text {dark }}$ and $A_{\text {pale }}$ as reserve and renewing stem cells respectively (Hermann et al. 2009). One possibility is that dark and pale nuclear morphologies correspond with the stage of the cell cycle (i.e. $G_{0}$ versus $\left.\mathrm{G}_{1} / S / \mathrm{G}_{2} / \mathrm{M}\right)$ and not with the distinct stem cell populations. Experiments are ongoing to determine whether nuclear morphology correlates with cell cycle stage. In addition, expression of NGN3 encompassed a transition from $\mathrm{KIT}^{-}$to $\mathrm{KIT}^{+}$within $\mathrm{A}_{\text {pale }}$ spermatogonia, suggesting that the initiation of NGN3 coincides with monkey spermatogenic differentiation. Future studies 
will begin to dissect this transition in $A_{\text {pale }}$ to identify regulatory networks that instruct spermatogonial differentiation in primates.

In rodents, spermatogonial clone size is associated with spermatogenic differentiation state; a spermatogonial clone differentiates, as it becomes larger. As discussed above (see Section 'Identity and arrangement of undifferentiated spermatogonia in primates'), there is limited information about the clonal arrangement of type-A spermatogonia in primates (Clermont 1969). We and others have begun to characterize the markers of undifferentiated (e.g. PLZF and GFRA1) versus differentiating (KIT) spermatogonia in primates. Thus, coupling immunohistochemical staining with spermatogonial clone size analysis in whole mount preparations of seminiferous tubules would provide valuable information correlating differentiation state with clone size in primates. Clonal analyses of this nature could elucidate the point in spermatogonial amplification (i.e. clone size) at which a differentiated phenotype begins to emerge. To this end, we have initiated studies to evaluate spermatogonial clones that exhibit undifferentiated $\left(\mathrm{PLZF}^{+}\right.$; Fig. 5A and B) or differentiating (KIT ${ }^{+}$; Fig. 5C and D) phenotypes using whole mount immunohistochemistry. We have taken the liberty of labeling some of these clones as single $(\mathrm{S})$, paired $(\mathrm{P})$, and aligned (Al) to stimulate thinking about how rhesus spermatogenic lineage development might compare/contrast with the rodent (Fig. 5).


Figure 5 Clonal organization of undifferentiated and differentiating spermatogonia in adult rhesus seminiferous tubules. Determining the clonal arrangement of undifferentiated and differentiating spermatogonia may be possible using whole mount immunohistochemistry in intact seminiferous tubules. In separate experiments, (A and B) undifferentiated $\left(\mathrm{PLZF}^{+}\right.$, green) or (C and D) differentiating $\left(\mathrm{KIT}^{+}\right.$, red $)$ spermatogonia were detected in adult rhesus seminiferous tubules. Some clones are identified in each panel as single $(\mathrm{S})$, pairs $(\mathrm{P})$, or aligned (Al). Scale bars $=25 \mu \mathrm{m}$. (BP Hermann \& KE Orwig, unpublished observations). Note: this is not a co-staining experiment.
There is a growing body of literature suggesting that rodent SSCs exhibit some degree of phenotypic, and perhaps functional, heterogeneity. For instance, several studies have shown that neurogenin 3 is expressed by a subset of spermatogonia with stem cell properties, suggesting subpopulations of SSCs with different functional roles or degrees of differentiation (Nakagawa et al. 2007, Yoshida et al. 2007, Zheng et al. 2009). A recent report suggests that GFRA1 expression is heterogeneous among $A_{\text {single }}$ spermatogonia in mice and among human $A_{\text {dark }}$ and $A_{\text {pale }}$ (Grisanti et al. 2009). Moreover, a recent study suggested that some spermatogonia expressing the differentiation marker KIT retained some degree of stem cell capacity and could repopulate the seminiferous epithelium under certain circumstances (Barroca et al. 2009). Additional studies are needed to validate these suggestions of stem cell heterogeneity and flexibility, expound on their implications for spermatogenesis, and define whether similar phenomena occur in primate testes.

Another emerging concept in the field is that there may be intraclonal heterogeneity among the earliest progeny of SSCs. Striking results have been observed in three separate studies where some undifferentiated spermatogonial clones $\left(A_{\text {paired }}\right.$ and $\left.A_{\text {aligned }}\right)$ exhibit this type of heterogeneity and some individual cells within a clone appear different from their clonal partners (Grisanti et al. 2009, Luo et al. 2009, Zheng et al. 2009). One interpretation of these data is that individual clones demonstrate asymmetry that could produce new SSCs when larger spermatogonial clones divide. These are infrequent observations (1.7-5\%) but reminiscent of the 'clone splitting' model of type-A spermatogonial selfrenewal and differentiation in primates (reviewed by Ehmcke \& Schlatt (2006)). To date, there are no other data supporting a mechanism of asymmetric division among clones of undifferentiated spermatogonia in rodents, but asymmetric division of germline stem cells is well established in flies (reviewed by Fuller \& Spradling (2007)).

\section{Conclusions}

For several decades, rodent spermatogenesis and primate spermatogenesis have been considered largely dissimilar with important biological differences in the identity and behavior of SSCs (Plant \& Marshall 2001). Concepts of rodent and primate spermatogenesis and SSC biology, however, were based largely on different experimental methodologies (Fig. 6A-C). Knowledge of primate testis biology lagged behind rodents, due in part to the dramatic differences in the relative volume of research conducted in these species, which are experimentally and evolutionarily disparate. Research on primate spermatogenesis (nonhuman and human) is poised for accelerated growth with improved access to validated reagents (e.g. antibodies for SSC markers) and 

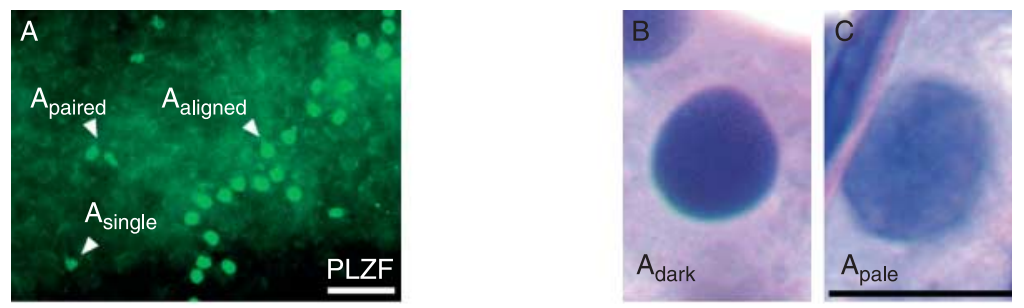

D

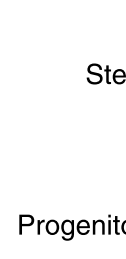

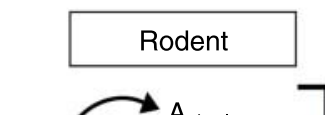

Stem Ц

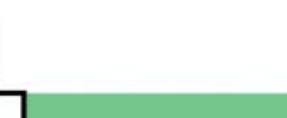

E

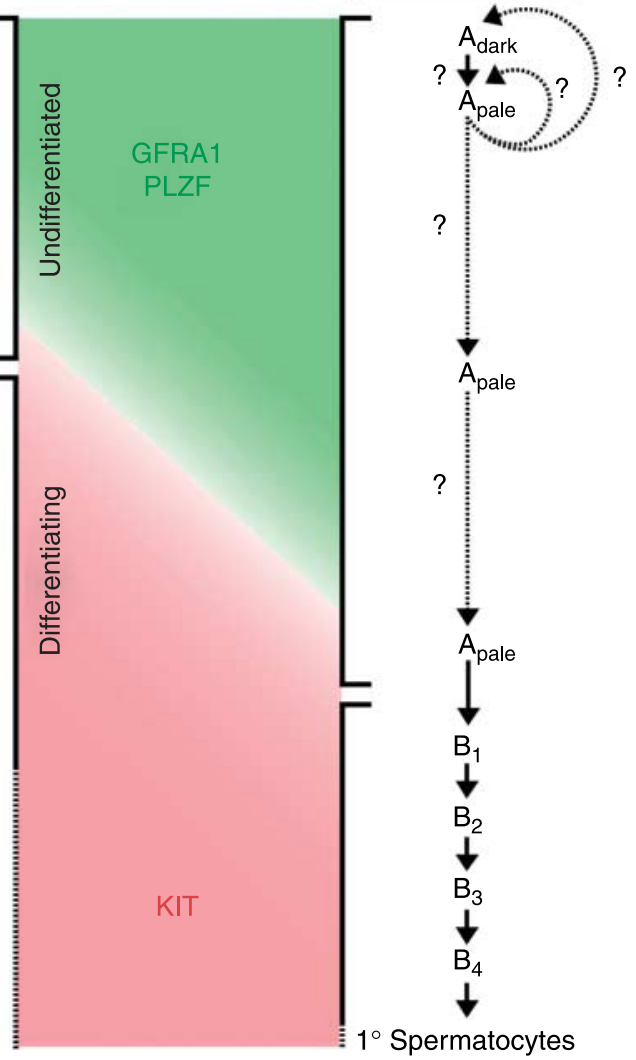

Figure 6 Current conceptual models of rodent and primate spermatogenesis. (A) Immunohistochemical staining for PLZF (green) was performed using whole mount preparations of adult rat seminiferous tubules, and clones of $\mathrm{PLZF}^{+}$spermatogonia were identified as $A_{\text {single }}, A_{\text {paired, }}$ or $A_{\text {aligned }}$ using the $25 \mu \mathrm{m}$ criteria (Huckins 1971, de Rooij \& Russell 2000). Scale bar $=50 \mu \mathrm{m}$. Sections of rhesus macaque testes were stained using the periodic acid-Schiff method and counterstained with Gills hematoxylin (Simorangkir et al. 2003) to reveal nuclear morphology and identify (B) $A_{\text {dark }}$ and (C) $A_{\text {pale }}$ spermatogonia. Scale bars $=10 \mu \mathrm{m}$. (D) Rodent undifferentiated spermatogonia are noted (bracket) including stem spermatogonia (SSCs) comprised $\mathrm{A}_{\text {singles }}$ and some $\mathrm{A}_{\text {paired }}$ spermatogonia that will complete cytokinesis to produce new $\mathrm{A}_{\text {singles }}$ and maintain the stem cell pool. Transit-amplifying progenitors include some $A_{\text {paired }}$ and $A_{\text {aligned }}$ spermatogonia (chains of 4-16 cells). Whole mount and transplantation analyses provided phenotypes for cells in these categories: stem $\left(\mathrm{A}_{\text {single }}\right.$ and some $\mathrm{A}_{\text {paired; }} \mathrm{GFRA} 1^{+}, \mathrm{PLZF}^{+}$, and $\mathrm{KIT}^{-}$), progenitor (some $\mathrm{A}_{\text {paired }}$ and $\mathrm{A}_{\text {aligned; }}$ $\mathrm{GFRA}^{+}{ }^{+}, \mathrm{PLZF}^{+}$, and $\mathrm{KIT}^{+/-}$) and differentiating (A1-4, intermediate, and B; GFRA ${ }^{-}{ }^{-}$PLZF $^{-}$, and $\mathrm{KIT}^{+}$). (E) In primate testes, undifferentiated (type-A) spermatogonia are designated $\mathrm{A}_{\text {dark }}$ and $A_{\text {pale }}$ based on nuclear architecture and staining intensity with hematoxylin. Recent progress has provided information about the molecular phenotype of $A_{\text {dark }}$ and $A_{\text {pale }}$ spermatogonia that allow alignment with rodent spermatogonia exhibiting a similar phenotype. The number of $A_{\text {pale }}$ generations is still not clear and may be resolved by future whole mount marker and clone size analysis (dotted arrows with question marks). experimental tools (e.g. xenotransplantation and xenografting; Jahnukainen et al. 2006, Hermann et al. 2007, Muller et al. 2008, Hermann et al. 2009, Maki et al. 2009). The molecular characteristics of $A_{\text {dark }}$ and $A_{\text {pale }}$ spermatogonia are beginning to emerge, allowing their alignment with subpopulations of undifferentiated rodent spermatogonia (i.e. $A_{\text {single, }} A_{\text {paired, }} A_{\text {aligned; }}$ Fig. $6 \mathrm{D}$ and $\mathrm{E}$ ), and identification of putative monkey SSCs (Fig. 3E). A Aark spermatogonia exhibit the most undifferentiated phenotype $\left(\mathrm{GFRA} 1^{+}, \mathrm{PLZF}^{+}\right.$, and $\mathrm{KIT}^{-}$). Additional studies will be required to determine whether $A_{\text {dark }}$ spermatogonia are truly reserve stem cells or whether these cells divide with sufficient frequency to participate in steady-state spermatogenesis of the adult monkey testis. While many $A_{\text {pale }}$ also exhibit this undifferentiated phenotype (GFRA ${ }^{+}, \mathrm{PLZF}^{+}$, and $\mathrm{KIT}^{-}$), some $A_{\text {pale }}$ appear phenotypically more similar to committed progenitor spermatogonia in rodents (i.e. $\mathrm{A}_{\text {aligned } 8-16 ;}$ GFRA1 ${ }^{+}, \mathrm{PLZF}^{+}$, and $\mathrm{KIT}^{+}$). This linear developmental ordering bears some resemblance to the 'A $\mathrm{A}_{\text {single' }}$ model of rodent spermatogenesis (Fig. 6D and E). Questions remain about whether $A_{\text {dark }}$ and $A_{\text {pale }}$ are 1) different stem cell populations, 2) parts of the same cell population, perhaps at different stages of the cell cycle, or 3) stem cells and progenitors respectively (Fig. 6E). In addition, more studies are needed to determine whether clone size correlates with differentiation state in primates, as it does in rodents (Fig. 6A) and whether clone size correlates with 'dark' and 'pale' descriptions of spermatogonial nuclear morphology (Fig. 6B and C). There is now increasing experimental momentum toward identifying and characterizing primate SSCs and the mechanisms by which they selfrenew and differentiate to produce spermatogenesis. 
This momentum is fueled by both the biological insights that it provides and the possible implications for treating human male infertility.

\section{Declaration of interest}

The authors declare that there is no conflict of interest that could be perceived as prejudicing the impartiality of the research reported.

\section{Funding}

Work performed in our laboratory was supported by the Magee-Womens Research Institute and Foundation, the Eunice Kennedy Shriver National Institute of Child Health and Human Development (NICHD/NIH) through cooperative agreement (U54 HD08160) as part of the Specialized Cooperative Centers Program in Reproduction and Infertility Research, NIH grants RR018500, AG024992, and HD055475 to K E Orwig, and an institutional NRSA postdoctoral fellowship (HD007332) to B P Hermann.

\section{References}

van Alphen MM \& de Rooij DG 1986 Depletion of the seminiferous epithelium of the rhesus monkey, Macaca mulatta, after X-irradiation. British Journal of Cancer Supplement 7 102-104.

van Alphen MM, van de Kant HJ \& de Rooij DG 1988 Repopulation of the seminiferous epithelium of the rhesus monkey after $X$ irradiation. Radiation Research 113 487-500.

Amann RP 2008 The cycle of the seminiferous epithelium in humans: a need to revisit? Journal of Andrology 29 469-487.

Barroca V, Lassalle B, Coureuil M, Louis JP, Le PF, Testart J, Allemand I, Riou L \& Fouchet P 2009 Mouse differentiating spermatogonia can generate germinal stem cells in vivo. Nature Cell Biology 11 190-196.

Bartmanska J \& Clermont Y 1983 Renewal of type A spermatogonia in adult rats. Cell and Tissue Kinetics 16 135-143.

Bellve AR, Cavicchia JC, Millette CF, O'Brien DA, Bhatnagar YM \& Dym M 1977 Spermatogenic cells of the prepuberal mouse. Isolation and morphological characterization. Journal of Cellular Biology 74 68-85.

Brinster RL 2007 Male germline stem cells: from mice to men. Science $\mathbf{3 1 6}$ 404-405.

Brinster RL \& Avarbock MR 1994 Germline transmission of donor haplotype following spermatogonial transplantation. PNAS 91 11303-11307.

Brinster RL \& Zimmermann JW 1994 Spermatogenesis following male germ-cell transplantation. PNAS 91 11298-11302.

Brinster CJ, Ryu BY, Avarbock MR, Karagenc L, Brinster RL \& Orwig KE 2003 Restoration of fertility by germ cell transplantation requires effective recipient preparation. Biology of Reproduction 69 412-420.

Buaas FW, Kirsh AL, Sharma M, McLean DJ, Morris JL, Griswold MD, de Rooij DG \& Braun RE 2004 Plzf is required in adult male germ cells for stem cell self-renewal. Nature Genetics 36 647-652.

Chowdhury AK \& Marshall GR 1980 Irregular pattern of spermatogenesis in the baboon (Papio anubis) and its possible mechanism. In Testicular Development, Structure and Function, pp 129-137. Eds A Steinberger \& E Steinberger. New York: Raven Press.

Chowdhury AK \& Steinberger E 1976 A study of germ cell morphology and duration of spermatogenic cycle in the baboon, Papio anubis. Anatomical Record 185 155-169.

Clermont Y 1963 The cycle of the seminiferous epithelium in man. American Journal of Anatomy 112 35-51.

Clermont Y 1966a Renewal of spermatogonia in man. American Journal of Anatomy 118 509-524.
Clermont Y $1966 b$ Spermatogenesis in man. A study of the spermatogonial population. Fertility and Sterility 17 705-721.

Clermont Y 1969 Two classes of spermatogonial stem cells in the monkey (Cercopithecus aethiops). American Journal of Anatomy 126 57-71.

Clermont Y 1972 Kinetics of spermatogenesis in mammals: seminiferous epithelium cycle and spermatogonial renewal. Physiological Reviews $\mathbf{5 2}$ 198-236.

Clermont Y \& Antar M 1973 Duration of the cycle of the seminiferous epithelium and the spermatogonial renewal in the monkey Macaca arctoides. American Journal of Anatomy 136 153-165.

Clermont Y \& Bustos-Obregon E 1968 Re-examination of spermatogonial renewal in the rat by means of seminiferous tubules mounted "in toto". American Journal of Anatomy 122 237-247.

Clermont Y \& Hermo L 1975 Spermatogonial stem cells in the albino rat. American Journal of Anatomy 142 159-175.

Clermont $\mathbf{Y}$ \& Leblond CP 1959 Differentiation and renewal of spermatogonia in the monkey, Macacus rhesus. American Journal of Anatomy 104 237-271.

Clermont Y \& Perey B 1957 The stages of the cycle of the seminiferous epithelium of the rat: practical definitions in PA-Schiff-hematoxylin and hematoxylin-eosin stained sections. Revue Canadienne de Biologie 16 451-462.

Clermont Y \& Trott M 1969 Duration of the cycle of the seminiferous epithelium in the mouse and hamster determined by means of 3H-thymidine and radioautography. Fertility and Sterility 20 805-817.

Clouthier DE, Avarbock MR, Maika SD, Hammer RE \& Brinster RL 1996 Rat spermatogenesis in mouse testis. Nature 381 418-421.

Conrad S, Renninger $M$, Hennenlotter J, Wiesner $T$, Just $L$, Bonin $\mathbf{M}$, Aicher W, Buhring HJ, Mattheus U, Mack A et al. 2008 Generation of pluripotent stem cells from adult human testis. Nature 456 344-349.

Dietrich T, Schulze W \& Riemer M 1986 Classification of the germinal epithelium in Java monkeys (Macaca cynomolgus) using digital image processing. Urologe A 25 179-186.

Dobrinski I, Avarbock MR \& Brinster RL 1999a Transplantation of germ cells from rabbits and dogs into mouse testes. Biology of Reproduction $\mathbf{6 1}$ 1331-1339.

Dobrinski I, Ogawa T, Avarbock MR \& Brinster RL 1999 b Computer assisted image analysis to assess colonization of recipient seminiferous tubules by spermatogonial stem cells from transgenic donor mice. Molecular Reproduction and Development 53 142-148.

Dobrinski I, Avarbock MR \& Brinster RL 2000 Germ cell transplantation from large domestic animals into mouse testes. Molecular Reproduction and Development 57 270-279.

Dym M \& Clermont Y 1970 Role of spermatogonia in the repair of the seminiferous epithelium following $\mathrm{x}$-irradiation of the rat testis. American Journal of Anatomy 128 265-282.

Dym M, Jia MC, Dirami G, Price JM, Rabin SJ, Mocchetti I \& Ravindranath $\mathbf{N} 1995$ Expression of c-kit receptor and its autophosphorylation in immature rat type A spermatogonia. Biology of Reproduction 52 8-19.

Dym M, Kokkinaki M \& He Z 2009 Spermatogonial stem cells: mouse and human comparisons. Birth Defects Research. Part C, Embryo Today 87 27-34.

Ehmcke J \& Schlatt S 2006 A revised model for spermatogonial expansion in man: lessons from non-human primates. Reproduction 132 673-680.

Ehmcke J, Luetjens CM \& Schlatt S 2005a Clonal organization of proliferating spermatogonial stem cells in adult males of two species of non-human primates, Macaca mulatta and Callithrix jacchus. Biology of Reproduction 72 293-300.

Ehmcke J, Simorangkir DR \& Schlatt S 2005b Identification of the starting point for spermatogenesis and characterization of the testicular stem cell in adult male rhesus monkeys. Human Reproduction 20 1185-1193.

Ehmcke J, Wistuba J \& Schlatt S 2006 Spermatogonial stem cells: questions, models and perspectives. Human Reproduction Update 12 275-282.

Falciatori I, Borsellino G, Haliassos N, Boitani C, Corallini S, Battistini L, Bernardi G, Stefanini M \& Vicini E 2004 Identification and enrichment of spermatogonial stem cells displaying side-population phenotype in immature mouse testis. FASEB Journal 18 376-378.

Fouquet JP \& Dadoune JP 1986 Renewal of spermatogonia in the monkey (Macaca fascicularis). Biology of Reproduction 35 199-207. 
Fritz IB 1986 Reflections on the evolution of the regulation of spermatogenesis. Progress in Clinical and Biological Research 226 371-388.

Fujita K, Ohta H, Tsujimura A, Takao T, Miyagawa Y, Takada S, Matsumiya K, Wakayama T \& Okuyama A 2005 Transplantation of spermatogonial stem cells isolated from leukemic mice restores fertility without inducing leukemia. Journal of Clinical Investigation 115 1855-1861.

Fuller MT \& Spradling AC 2007 Male and female Drosophila germline stem cells: two versions of immortality. Science $316402-404$.

Greenbaum MP, Yan W, Wu MH, Lin YN, Agno JE, Sharma M, Braun RE, Rajkovic A \& Matzuk MM 2006 TEX14 is essential for intercellular bridges and fertility in male mice. PNAS 103 4982-4987.

Grisanti L, Falciatori I, Grasso M, Dovere L, Fera S, Muciaccia B, Fuso A, Berno V, Boitani C, Stefanini M et al. 2009 Identification of spermatogonial stem cell subsets by morphological analysis and prospective isolation. Stem Cells 27 3043-3052.

Gupta G, Maikhuri JP, Setty BS \& Dhar JD 2000 Seasonal variations in daily sperm production rate of rhesus and bonnet monkeys. Journal of Medical Primatology 29 411-414.

Heller CG \& Clermont Y 1963 Spermatogenesis in man: an estimate of its duration. Science 140 184-186.

Hermann BP, Sukhwani M, Lin CC, Sheng Y, Tomko J, Rodriguez M, Shuttleworth JJ, McFarland D, Hobbs RM, Pandolfi PP et al. 2007 characterization, cryopreservation and ablation of spermatogonial stem cells in adult rhesus macaques. Stem Cells 25 2330-2338.

Hermann BP, Sukhwani M, Simorangkir DR, Chu T, Plant TM \& Orwig KE 2009 Molecular dissection of the male germ cell lineage identifies putative spermatogonial stem cells in rhesus macaques. Human Reproduction 24 1704-1716.

Holt WV \& Moore HD 1984 Ultrastructural aspects of spermatogenesis in the common marmoset (Callithrix jacchus). Journal of Anatomy 138 175-188.

Honaramooz A, Megee SO \& Dobrinski I 2002 Germ cell transplantation in pigs. Biology of Reproduction 66 21-28.

Honaramooz A, Behboodi E, Megee SO, Overton SA, Galantino-Homer H, Echelard Y \& Dobrinski I 2003 Fertility and germline transmission of donor haplotype following germ cell transplantation in immunocompetent goats. Biology of Reproduction 69 1260-1264.

Huckins C 1971 The spermatogonial stem cell population in adult rats. I. Their morphology, proliferation and maturation. Anatomical Record 169 533-557.

Izadyar F, Den OK, Stout TA, Stout J, Coret J, Lankveld DP, Spoormakers TJ, Colenbrander B, Oldenbroek JK, Van der Ploeg KD et al. 2003 Autologous and homologous transplantation of bovine spermatogonial stem cells. Reproduction 126 765-774.

Jahnukainen K, Ehmcke J \& Schlatt S 2006 Testicular xenografts: a novel approach to study cytotoxic damage in juvenile primate testis. Cancer Research 66 3813-3818.

Kanatsu-Shinohara M, Toyokuni S, Morimoto T, Matsui S, Honjo T \& Shinohara T 2003 Functional assessment of self-renewal activity of male germline stem cells following cytotoxic damage and serial transplantation. Biology of Reproduction 68 1801-1807.

Kanatsu-Shinohara M, Toyokuni S \& Shinohara T 2004 CD9 is a surface marker on mouse and rat male germline stem cells. Biology of Reproduction 70 70-75.

Kanatsu-Shinohara M, Inoue K, Miki H, Ogonuki N, Takehashi M, Morimoto T, Ogura A \& Shinohara T 2006 Clonal origin of germ cell colonies after spermatogonial transplantation in mice. Biology of Reproduction 75 68-74.

Kim Y, Turner D, Nelson J, Dobrinski I, McEntee M \& Travis A 2008 Production of donor-derived sperm after spermatogonial stem cell transplantation in the dog. Reproduction 136 823-831.

Kluin PM, Kramer MF \& de Rooij DG 1982 Spermatogenesis in the immature mouse proceeds faster than in the adult. International Journal of Andrology 5 282-294.

Kluin PM, Kramer MF \& de Rooij DG 1983 Testicular development in Macaca irus after birth. International Journal of Andrology 6 25-43.

Kubota H, Avarbock MR \& Brinster RL 2003 Spermatogonial stem cells share some, but not all, phenotypic and functional characteristics with other stem cells. PNAS 100 6487-6492.
Lassalle B, Bastos H, Louis JP, Riou L, Testart J, Dutrillaux B, Fouchet P \& Allemand I 2004 'Side Population' cells in adult mouse testis express Bcrp1 gene and are enriched in spermatogonia and germinal stem cells. Development 131 479-487.

Leblond CP \& Clermont Y 1952 Definition of the stages of the cycle of the seminiferous epithelium in the rat. Annals of the New York Academy of Sciences 55 548-573.

Lo KC, Brugh VM III, Parker M \& Lamb DJ 2005 Isolation and enrichment of murine spermatogonial stem cells using rhodamine 123 mitochondrial dye. Biology of Reproduction 72 767-771.

Lok D, Weenk D \& de Rooij DG 1982 Morphology, proliferation, and differentiation of undifferentiated spermatogonia in the Chinese hamster and the ram. Anatomical Record 203 83-99.

Luo J, Megee S \& Dobrinski I 2009 Asymmetric distribution of UCH-L1 in spermatogonia is associated with maintenance and differentiation of spermatogonial stem cells. Journal of Cellular Physiology 220 460-468.

Maki CB, Pacchiarotti J, Ramos T, Pascual M, Pham J, Kinjo J, Anorve S \& Izadyar F 2009 Phenotypic and molecular characterization of spermatogonial stem cells in adult primate testes. Human Reproduction $\mathbf{2 4}$ 1480-1491.

Manova K, Nocka K, Besmer P \& Bachvarova RF 1990 Gonadal expression of c-kit encoded at the W locus of the mouse. Development $\mathbf{1 1 0}$ 1057-1069.

Marshall GR \& Plant TM 1996 Puberty occurring either spontaneously or induced precociously in rhesus monkey (Macaca mulatta) is associated with a marked proliferation of Sertoli cells. Biology of Reproduction 54 1192-1199.

Miething A 1998 The establishment of spermatogenesis in the seminiferous epithelium of the pubertal golden hamster (Mesocricetus auratus). Advances in Anatomy, Embryology, and Cell Biology 140 1-92.

Mikkola M, Sironen A, Kopp C, Taponen J, Sukura A, Vilkki J, Katila T \& Andersson M 2006 Transplantation of normal boar testicular cells resulted in complete focal spermatogenesis in a boar affected by the immotile short-tail sperm defect. Reproduction in Domestic Animals 41 124-128.

Millar MR, Sharpe RM, Weinbauer GF, Fraser HM \& Saunders PT 2000 Marmoset spermatogenesis: organizational similarities to the human. International Journal of Andrology 23 266-277.

Mitchell RT, Cowan G, Morris KD, Anderson RA, Fraser HM, Mckenzie KJ, Wallace WH, Kelnar CJ, Saunders PT \& Sharpe RM 2008 Germ cell differentiation in the marmoset (Callithrix jacchus) during fetal and neonatal life closely parallels that in the human. Human Reproduction 23 2755-2765.

Muller T, Eildermann K, Dhir R, Schlatt S \& Behr R 2008 Glycan stem-cell markers are specifically expressed by spermatogonia in the adult nonhuman primate testis. Human Reproduction 23 2292-2298.

Myoga H, Sung WK \& Jagiello G 1991 The cycle of the seminiferous epithelium of the Turkish hamster (Mesocricetus brandti). Development Growth and Differentiation 33 599-604.

Nagano M \& Brinster RL 1998 Spermatogonial transplantation and reconstitution of donor cell spermatogenesis in recipient mice. Acta Pathologica, Microbiologica, et Immunologica Scandinavica 106 47-57.

Nagano M, Avarbock MR \& Brinster RL 1999 Pattern and kinetics of mouse donor spermatogonial stem cell colonization in recipient testes. Biology of Reproduction 60 1429-1436.

Nagano M, Brinster CJ, Orwig KE, Ryu BY, Avarbock MR \& Brinster RL 2001a Transgenic mice produced by retroviral transduction of male germ-line stem cells. PNAS 98 13090-13095.

Nagano M, McCarrey JR \& Brinster RL 2001b Primate spermatogonial stem cells colonize mouse testes. Biology of Reproduction $\mathbf{6 4}$ 1409-1416.

Nagano M, Patrizio P \& Brinster RL 2002 Long-term survival of human spermatogonial stem cells in mouse testes. Fertility and Sterility $\mathbf{7 8}$ 1225-1233.

Nakagawa T, Nabeshima Y \& Yoshida S 2007 Functional identification of the actual and potential stem cell compartments in mouse spermatogenesis. Developmental Cell 12 195-206.

Oakberg EF 1956 A description of spermiogenesis in the mouse and its use in analysis of the cycle of the seminiferous epithelium and germ cell renewal. American Journal of Anatomy 99 391-413. 
Oakberg EF 1971 Spermatogonial stem-cell renewal in the mouse. Anatomical Record 169 515-531.

Oatley JM, de Avila DM, McLean DJ, Griswold MD \& Reeves JJ 2002 Transplantation of bovine germinal cells into mouse testes. Journal of Animal Science 80 1925-1931.

Ogawa T, Aréchaga JM, Avarbock MR \& Brinster RL 1997 Transplantation of testis germinal cells into mouse seminiferous tubules. International Journal of Developmental Biology 41 111-122.

Ogawa T, Dobrinski I, Avarbock MR \& Brinster RL 1999 Xenogeneic spermatogenesis following transplantation of hamster germ cells to mouse testes. Biology of Reproduction 60 515-521.

Ogawa T, Dobrinski I, Avarbock MR \& Brinster RL 2000 Transplantation of male germ line stem cells restores fertility in infertile mice. Nature Medicine 6 29-34.

Ohta H, Yomogida K, Yamada S, Okabe M \& Nishimune Y 2000 Real-time observation of transplanted 'green germ cells': proliferation and differentiation of stem cells. Development, Growth and Differentiation 42 105-112.

Orwig KE \& Schlatt S 2005 Cryopreservation and transplantation of spermatogonia and testicular tissue for preservation of male fertility. Journal of the National Cancer Institute. Monographs 34 51-56.

Orwig KE, Ryu BY, Master SR, Phillips BT, Mack M, Avarbock MR, Chodosh L \& Brinster RL 2008 Genes involved in post-transcriptional regulation are overrepresented in stem/progenitor spermatogonia of cryptorchid mouse testes. Stem Cells 26 927-938.

Oud JL \& de Rooij DG 1977 Spermatogenesis in the Chinese hamster. Anatomical Record 187 113-124.

Plant TM \& Marshall GR 2001 The functional significance of FSH in spermatogenesis and the control of its secretion in male primates. Endocrine Reviews 22 764-786.

de Rooij DG 1973 Spermatogonial stem cell renewal in the mouse. I. Normal situation. Cell and Tissue Kinetics 6 281-287.

de Rooij DG \& Russell LD 2000 All you wanted to know about spermatogonia but were afraid to ask. Journal of Andrology 21 776-798.

de Rooij DG, van Alphen MM \& van de Kant HJ 1986 Duration of the cycle of the seminiferous epithelium and its stages in the rhesus monkey (Macaca mulatta). Biology of Reproduction 35 587-591.

Rosiepen G, Arslan M, Clemen G, Nieschlag E \& Weinbauer GF 1997 Estimation of the duration of the cycle of the seminiferous epithelium in the non-human primate Macaca mulatta using the 5-bromodeoxyuridine technique. Cell and Tissue Research 288 365-369.

Ryu BY, Orwig KE, Avarbock MR \& Brinster RL 2003 Stem cell and niche development in the postnatal rat testis. Developmental Biology 263 253-263.

Ryu BY, Orwig KE, Kubota H, Avarbock MR \& Brinster RL 2004 Phenotypic and functional characteristics of spermatogonial stem cells in rats. Developmental Biology 274 158-170.

Schlatt S \& Weinbauer GF 1994 Immunohistochemical localization of proliferating cell nuclear antigen as a tool to study cell proliferation in rodent and primate testes. International Journal of Andrology $\mathbf{1 7}$ 214-222.

Schlatt S, Ehmcke J \& Jahnukainen K 2009 Testicular stem cells for fertility preservation: preclinical studies on male germ cell transplantation and testicular grafting. Pediatric Blood \& Cancer 53 274-280.

Schlesser HN, Simon L, Hofmann MC, Murphy KM, Murphy T, Hess RA \& Cooke PS 2008 Effects of ETV5 (ets variant gene 5) on testis and body growth, time course of spermatogonial stem cell loss, and fertility in mice. Biology of Reproduction 78 483-489.

Schrans-Stassen BH, van de Kant HJ, de Rooij DG \& van Pelt AM 1999 Differential expression of c-kit in mouse undifferentiated and differentiating type A spermatogonia. Endocrinology 140 5894-5900.

Sharpe RM 1994 Regulation of spermatogenesis. In The Physiology of Reproduction, pp 1363-1434. Eds E Knobil \& JD Neill. New York: Raven Press, Ltd.
Shinohara T, Avarbock MR \& Brinster RL 1999 b1- and a6-integrin are surface markers on mouse spermatogonial stem cells. PNAS $\mathbf{9 6}$ 5504-5509.

Shinohara T, Orwig KE, Avarbock MR \& Brinster RL 2000 Spermatogonial stem cell enrichment by multiparameter selection of mouse testis cells. PNAS 97 8346-8351.

Shinohara T, Orwig KE, Avarbock MR \& Brinster RL 2001 Remodeling of the postnatal mouse testis is accompanied by dramatic changes in stem cell number and niche accessibility. PNAS 98 6186-6191.

Simorangkir DR, Marshall GR \& Plant TM 2003 Sertoli cell proliferation during prepubertal development in the rhesus monkey (Macaca mulatta) is maximal during infancy when gonadotropin secretion is robust. Journal of Clinical Endocrinology and Metabolism 88 4984-4989.

Simorangkir DR, Marshall GR \& Plant TM 2009 A re-examination of proliferation and differentiation of type A spermatogonia in the adult rhesus monkey (Macaca mulatta). Human Reproduction 24 1584-1595.

Smithwick EB \& Young LG 1996 Germ cell maturation and cellular associations in the seminiferous epithelial cycle of the chimpanzee. Tissue Cell 28 137-148.

Smithwick EB, Young LG \& Gould KG 1996 Duration of spermatogenesis and relative frequency of each stage in the seminiferous epithelial cycle of the chimpanzee. Tissue Cell 28 357-366.

Sorrentino V, Giorgi M, Geremia R, Besmer P \& Rossi P 1991 Expression of the c-kit proto-oncogene in the murine male germ cells. Oncogene $\mathbf{6}$ 149-151.

Tajima Y, Sawada K, Morimoto T \& Nishimune Y 1994 Switching of mouse spermatogonial proliferation from the c-kit receptor-independent type to the receptor-dependent type during differentiation. Journal of Reproduction and Fertility 102 117-122.

Tegelenbosch RAJ \& de Rooij DG 1993 A quantitative study of spermatogonial multiplication and stem cell renewal in the $\mathrm{C} 3 \mathrm{H} / 101$ F1 hybrid mouse. Mutation Research 290 193-200.

Thayer KA, Ruhlen RL, Howdeshell KL, Buchanan DL, Cooke PS, Preziosi D, Welshons WV, Haseman J \& vom Saal FS 2001 Altered prostate growth and daily sperm production in male mice exposed prenatally to subclinical doses of 17alpha-ethinyl oestradiol. Human Reproduction 16 988-996.

Tokuda M, Kadokawa Y, Kurahashi H \& Marunouchi T 2007 CDH1 is a specific marker for undifferentiated spermatogonia in mouse testes. Biology of Reproduction 76 130-141.

Yoshida S, Takakura A, Ohbo K, Abe K, Wakabayashi J, Yamamoto M, Suda T \& Nabeshima Y-I 2004 Neurogenin3 delineates the earliest stages of spermatogenesis in the mouse testis. Developmental Biology 269 447-458.

Yoshida S, Nabeshima Y \& Nakagawa T 2007 Stem cell heterogeneity: actual and potential stem cell compartments in mouse spermatogenesis. Annals of the New York Academy of Sciences 1120 47-58.

Yoshinaga K, Nishikawa S, Ogawa M, Hayashi S, Kunisada T, Fujimoto T \& Nishikawa S 1991 Role of c-kit in mouse spermatogenesis: identification of spermatogonia as a specific site of c-kit expression and function. Development 113 689-699.

Zhang X, Ebata KT \& Nagano MC 2003 Genetic analysis of the clonal origin of regenerating mouse spermatogenesis following transplantation. Biology of Reproduction 69 1872-1878.

Zheng K, Wu X, Kaestner KH \& Wang PJ 2009 The pluripotency factor LIN28 marks undifferentiated spermatogonia in mouse. BMC Developmental Biology 938.

Received 22 June 2009

First decision 4 August 2009

Revised manuscript received 6 October 2009

Accepted 30 October 2009 